\title{
遠心載荷実験装置を用いた上屋・杭基礎一地盤系における 液状化地盤の杭頭補強鋼管杭の終局耐力評価 \\ DYNAMIC ULTIMATE STRENGTH FOR CIRCULAR TUBE PILE STIFFENED AT PILE HEAD BASED ON CENTRIFUGE TESTS OF SUPERSTRUCTURE-PILE-LIQUEFIED SOIL SYSTEM
}

\author{
木 村 祥 裕 $^{* 1}$, 的場 萌子*2, 後藤 天志郎*2, 田村修 次 ${ }^{* 3}$ \\ Yoshihiro KIMURA, Moeko MATOBA, Tenshiro GOTO \\ and Shuji TAMURA
}

\begin{abstract}
In our previous paper, centrifuge tests of superstructure-pile-liquefied soil systems have been conducted, and dynamic ultimate mechanism of steel piles subjected to the vertical force and horizontal force in the liquefied soil was clarified. It is shown that piles' ultimate strength was estimated using the M-N interaction curves. On the other hand, for real structures, reinforced concrete is filled at a pile head to fix a connection between steel piles and a reinforced concrete footing beam. In this paper, ultimate strength of the pile stiffened at the pile head is estimated using M-N interaction curves with pile's equivalent buckling slenderness ratio.
\end{abstract}

Keywords: Circular Tube Piles, Stiffener at Pile Top, Centrifuge Tests, Reversed Axial F orce, Lateral F orce, Liquefied Soil, F lexural Buckling Strength, Ultimate Strength

鋼管杭，杭頭補強，遠心載荷実験，液状化，曲げ座屈耐力，終局耐力

1. 序

現行の建築基礎構造設計指針 ${ }^{1)}$ では, 鋼管杭と RC 基礎梁の接合 部におけるせん断抵抗力の補強と鉛直荷重の伝達の目的で，杭頭部 にコンクリートを中詰めし，鉄筋を基礎スラブ内に定着させる方法

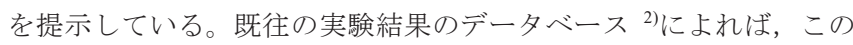
ような接合方法は，杭頭部で高い回転剛性を確保できることが示さ れている。その際，杭頭部のコンクリート中詰め長さは杭径の 3 倍 以下とされているものの, 施工上の問題から実際には杭径と同じ長 さとするケースが多い。

一方, RC 系杭に比べて薄肉断面である鋼管杭には上屋の自重に より降伏軸力の $50 \%$ 以上, 地震時には上屋の転倒モーメントに伴う 偶力により終局時に 70 80\%程度の圧縮軸力が作用することもある が，過去の地震被害事例 ${ }^{3)}$ では杭の曲げ座屈は液状化地盤においても報 告されていないことから, 現行の設計指針 ${ }^{1)}$ では, 鉛直荷重による杭の 曲げ座屈を想定していない。一方で, 著者らは地盤の液状化に伴う鋼 管杭の曲げ座屈耐力挙動を有限要素法による弾塑性大変形解析によ り明らかにした。また, エネルギー法により誘導した杭の弾性曲げ 座屈荷重式を適用した修正一般化細長比を用いて, 液状化地盤にお いて杭頭に圧縮軸力が作用する鋼管杭の曲げ座屈耐力を評価した 4)5)6)。これらの知見は, 静的荷重による杭の弾塑性挙動であり, 地 震時には動的荷重が作用することから, 文献 7)では基礎部の水平変 形を拘束し, 地盤の液状化時に上屋の転倒モーメントに伴い，杭に 変動軸力のみが作用する杭基礎・上屋一地盤系の遠心載荷実験を行

*1 東北大学末来科学技術共同研究センター 教授・博士 (工学)

*2 東北大学大学院工学研究科都市·建築学専攻

*3 東京工業大学環境 $\cdot$ 社会理工学院建築学系 准教授・博士 (工学)
い, 杭の動座屈挙動を明らかにした。一方で, 実際の構造物では基 礎部に水平変形が生じ, 地盤の液状化に伴い上屋の加速度応答が低 下寸ることから, 上屋の水平変形による軸力変動は小さくなる。現 行の設計指針 ${ }^{1)}$ では, 曲げモーメントと軸力の相関を考慮した M-N 耐力曲線により耐力式を設定しているが, 液状化層において圧縮力 を受ける杭の曲げ座屈耐力を考慮していない。そこで, 文献 8)では 液状化地盤における杭の曲げ座屈を考慮し, 杭の終局耐力を鋼構造 限界状態設計指針・同解説 ${ }^{9)}$ (以降, 限界状態設計指針と呼ぶ）の 座屈耐力を適用した M-N 耐力曲線 ${ }^{1}$ により評価できることを示した。 以上より, 液状化地盤において動的曲げ座屈を生じる鋼管杭の終 局耐力を評価できるものの, 杭頭部にコンクリートを中詰めした杭 は対象ではない。地下水位が高く, 杭頭部まで地盤が液状化する場 合, 杭頭部の中詰めの効果により, せん断抵抗力の補強および鉛直 荷重の伝達だけでなく, 中詰め領域の曲げ岡性が局所的に大きくな ることから, 鋼管杭の座屈長さを低減するものと考えられる(以降, 鋼管杭頭部へのコンクリート充填を杭頭補強と呼ぶ)。

本論文では, 縮小模型による上屋・杭基礎一地盤系の遠心載荷実 験を行い, 杭頭補強鋼管杭の終局挙動を明らかにする。第 2 章では, 遠心載荷実験及び杭の数值解析モデルを概説する。第 3 章では, 鉛 直荷重のみを受ける杭頭補強鋼管杭を対象として, エネルギー法に より誘導した弾性曲げ座屈荷重を適用した修正一般化細長比による 座屈曲線 ${ }^{9110)}$ によ, 弾塑性大変形解析から得られた杭の弾塑性曲

Prof., New Industry Creation Hatchery Center, Tohoku University, Dr. Eng. Graduate School of Tohoku University

Assoc. Prof., School of Environment and Society, Tokyo Institute of

Technology, Dr. Eng. 
表 1 試験体諸元

\begin{tabular}{|c|c|c|c|c|}
\hline & & 項目 & $\begin{array}{c}\text { 模型 } \\
\text { スケール }\end{array}$ & $\begin{array}{c}\text { 実大 } \\
\text { スケール }\end{array}$ \\
\hline \multicolumn{2}{|c|}{ 上屋構造物 $\mathrm{m}_{1}$} & 重量(N) & 66.7 & $4.27 \times 10^{6}$ \\
\hline \multicolumn{2}{|c|}{ 板バネ } & 板厚 $(\mathrm{mm})$ & 2 & 80 \\
\hline \multicolumn{2}{|c|}{ 基礎部 $\mathrm{m}_{2}$} & 重量(N) & 13.0 & $8.3 \times 10^{5}$ \\
\hline \multirow{4}{*}{ 杭材 } & \multirow{4}{*}{ 真鍮 } & 長さ I(mm) & 265 & 10600 \\
\hline & & 外径 D (mm) & 10 & 400 \\
\hline & & 板厚 t(mm) & 0.2 & 8.0 \\
\hline & & $\begin{array}{c}\text { 曲げ剛性 } \\
\mathrm{E}_{\mathrm{s}} \mathrm{l}_{\mathrm{s}}\left(\mathrm{N} \cdot \mathrm{mm}^{2}\right)\end{array}$ & $7.62 \times 10^{6}$ & $1.95 \times 10^{13}$ \\
\hline \multirow{3}{*}{$\begin{array}{l}\text { 中詰 } \\
\text { 部材 }\end{array}$} & \multirow{3}{*}{ アルミ } & $\begin{array}{c}\text { 補強部長さ } \\
\text { nD (mm) }\end{array}$ & $10 n$ & $400 n$ \\
\hline & & 外径(mm) & 9.6 & 384 \\
\hline & & $\begin{array}{c}\text { 曲げ剛性 } \\
\mathrm{E}_{\mathrm{a}} \mathrm{I}_{\mathrm{a}}\left(\mathrm{N} \cdot \mathrm{mm}^{2}\right)\end{array}$ & $2.74 \times 10^{7}$ & $7.02 \times 10^{13}$ \\
\hline
\end{tabular}

表 2 材料特性 (単位 $\left[\mathrm{N} / \mathrm{mm}^{2}\right]$ )

\begin{tabular}{|c||c|c|}
\hline & 真鍮 & アルミ \\
\hline 弾性比例限界応力度 $\sigma$ & 275 & 115 \\
\hline 降伏応力度 $\sigma_{\mathrm{y}}$ & 398 & 136 \\
\hline 引張強度 $\sigma_{\mathrm{u}}$ & 498 & 145 \\
\hline ヤング率 $\mathrm{E}$ & 103000 & 65800 \\
\hline 歪硬化勾配 $\mathrm{E}_{\mathrm{st}}$ & 17200 & 727 \\
\hline
\end{tabular}

げ座屈耐力の評価を試みる。また，遠心載荷実験により杭頭補強 杭が変動軸力を受けるときの動的曲げ座屈挙動（以降, 動座屈挙 動と呼ぶ）を明らかにする。第 4 章では，弾塑性大変形解析によ り軸力と水平力を受ける, 杭頭補強杭の終局挙動を把握し, 杭頭 補強杭一上屋 - 液状化地盤系の遠心載荷実験を行い, 軸力と水平 力を受ける杭頭補強杭の終局挙動に及ぼす補強効果を明らかにす る。さらに，第 3 章で求めた座屈曲線を，現行の設計指針 ${ }^{119)}$ の $\mathrm{M}-\mathrm{N}$ 設計耐力曲線，M-N 設計耐力線及び文献 11)の終局耐力曲線 に適用することで，実験より得られた杭終局時の作用軸力と作用 曲げモーメントを評価するとともに，杭頭補強による杭の保有性 能向上についても検討する。

\section{2. 遠心載荷実験及び数值解析概要}

本章では，杭頭補強鋼管杭・上屋－液状化地盤系の遠心載荷実験 及び鋼管単杭一液状化地盤モデルによる有限要素解析を概説する。

\section{1 遠心載荷装置を用いた杭頭補強杭の動座屈実験概要}

図 1 に実験試験体及び計測位置を示す。試験体は上屋・杭基礎一 地盤系とし，上屋構造物の高さは $90 \mathrm{~mm} ，$ 幅は $120 \mathrm{~mm}$ である。これ ら及びせん断土槽の形状は文献 7) と同一のものである。乾燥した豊 浦硅砂を空中から散布し堆積させる空中落下法により地盤を製作し， 粘性を水の約 40 倍に調整したメトローズ溶液を用いて地盤を飽和 させた。水位は基礎部の直下 $(\mathrm{GL}-0 \mathrm{~m})$ である。手前の 2 本の杭のう ち左側を A，右側 B とし，それぞれの奥の杭を C，Dとする。板バ ネについては左側を X，右側を Y とする。杭頭部は図 1(c)に示すよ うに杭を基礎部に貫通させ，機械切削により杭内径に対して誤差 $-0.01 \mathrm{~mm}$ 未満の径を有する中実丸棒のキャップを杭に差し込み, 中 実丸棒キャップの長さを調節することで，杭頭補強部長さを再現し ている。本試験体の杭頭補強部長さは, 実構造物の中詰長さを参考 に，一般的に用いられる $1 D$ 及び最大長さ $3 D$ (D : 杭径) とする。

歪ゲージの貼付位置は図 1(b), (e)に示すとおりであり，杭及び板 バネの両面に対しそれぞれ $x_{i}, y_{i}$ として, 杭については上端から $i=1 \sim 7$, 板バネについては $\mathrm{i}=1 \sim 3$ とする。杭頭補強杭の場合, 歪ゲージ位置 は図 1(b), (c)のように $\mathrm{i}=1$ が中詰部材充填部, $\mathrm{i}=2 \sim 7$ が非充填部と
表 3 試験体パラメータ（模型スケール）

\begin{tabular}{|c|c|c|c|c|c|c|}
\hline $\begin{array}{c}\text { 杭材長さ } \\
\text { I (mm) } \\
\text { (細長比) }\end{array}$ & $\begin{array}{l}\text { 径 } \\
\text { 厚 } \\
\text { 比 }\end{array}$ & $\begin{array}{c}\text { 板バネ } \\
\text { 長さ } \\
\text { h (mm) }\end{array}$ & $\begin{array}{c}\text { 地盤の } \\
\text { 相対密度 } \\
\text { Dr (\%) }\end{array}$ & $\begin{array}{c}\text { 補強部 } \\
\text { 長さ } \\
n D\end{array}$ & 入力波 & $\begin{array}{c}\text { 入力最大 } \\
\text { 加速度 } \\
\left(\mathrm{m} / \mathrm{s}^{2}\right)\end{array}$ \\
\hline \multirow{5}{*}{$\begin{array}{l}260 \\
(75)\end{array}$} & \multirow{10}{*}{50} & \multirow{5}{*}{35} & & 0 & \multirow{5}{*}{ sweep } & \multirow{5}{*}{3.0} \\
\hline & & & & $1 \mathrm{D}$ & & \\
\hline & & & & $3 \mathrm{D}$ & & \\
\hline & & & \multirow{2}{*}{30} & 0 & & \\
\hline & & & & $1 D$ & & \\
\hline \multirow{5}{*}{$\begin{array}{c}265 \\
(78)\end{array}$} & & \multirow{5}{*}{55} & \multirow{3}{*}{30} & 0 & \multirow{5}{*}{ 臨海波 } & \multirow{5}{*}{5.0} \\
\hline & & & & $1 D$ & & \\
\hline & & & & $3 \mathrm{D}$ & & \\
\hline & & & \multirow{2}{*}{60} & 0 & & \\
\hline & & & & $1 D$ & & \\
\hline
\end{tabular}

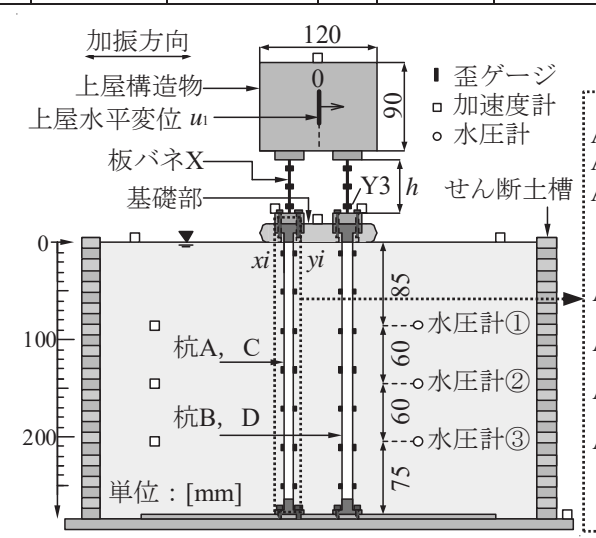

(a) 実験試験体

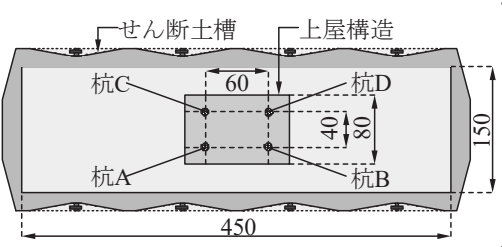

（d）試験体及び土槽平面図

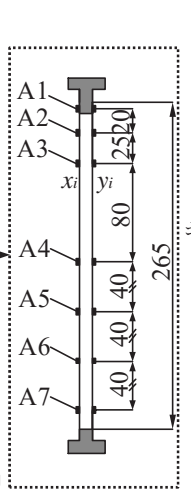

(b) 杭 A 拡大図と 歪ゲージ位置
基礎部 板バネ

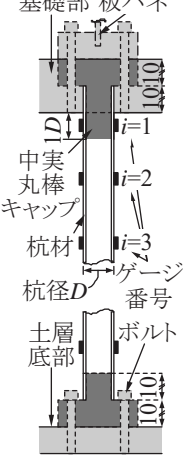

(c) 杭頭·下端 部詳細図 (d) 試験体及び土槽平面図

なる。また, 土槽底部 (杭下端), 基礎部, 上屋頂部に加速度計を設 置し，地盤中に地表面から 85，145，205mm の位置に間隙水圧計と 加速度計をそれぞれ設置している。加振方向の上屋構造物水平変位 は, 試験体上屋側面にレーザー変位計の焦点をあてて測定している。

なお，実験試験体は，板バネの曲げ剛性に比べ基礎部の曲げ剛性 が非常に大きいため，基礎部の曲げは生じず，また，動座屈発生ま では高い軸剛性を有する杭が基礎部のロッキング振動を抑えている ことを確認している。本論文の遠心載荷実験は, 京都大学防災研究 所の遠心載荷装置を用いて $40 \mathrm{~g}$ 場で行った。

表 1 に試験体の諸元を示す。杭材には真鍮 C2680, 中詰部材には アルミA1050S，板バネにはアルミA5052を用い，その他の部材に は SS400 を用いる。杭材及び中詰部材に用いた真鍮とアルミの材料 特性は文献 8) と同一の Round House 型であり，明瞭な降伏点を持た ないことから弾性比例限界応力度 $\sigma$ を定め, 降伏応力度 $\sigma_{\mathrm{y}}$ を $0.2 \%$ 才 フセット法により求めている。表 2 にこれらの弾性比例限界応力度 $\sigma$, 降伏応力度 $\sigma_{\mathrm{y}}$, 引張強度 $\sigma_{\mathrm{u}}$, ヤング率 $\mathrm{E}$, 歪硬化勾配 $\mathrm{E}_{\mathrm{st}}$ を示す。

表 3 に試験体一覧を示す。Case1 は基礎部の水平移動を拘束した 場合, すなわち杭に軸力のみが作用することを想定したものである。 Case2 は基礎部の水平移動を許容し，杭に軸力と水平力が作用する 場合である。試験体の降伏軸力 $\mathrm{N}_{\mathrm{y}}$ に対する初期圧縮軸力 $\mathrm{N}_{0}$ の比 $\mathrm{N}_{0} / \mathrm{N}_{\mathrm{y}}$ は，実構造物における鋼管杭の設計軸力を参考に 0.33 として 


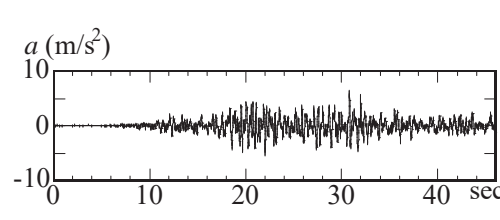

図 2 入力波時刻歴(臨海波)

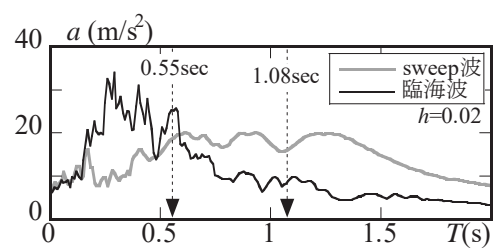

図 3 入力波応答スペクトル

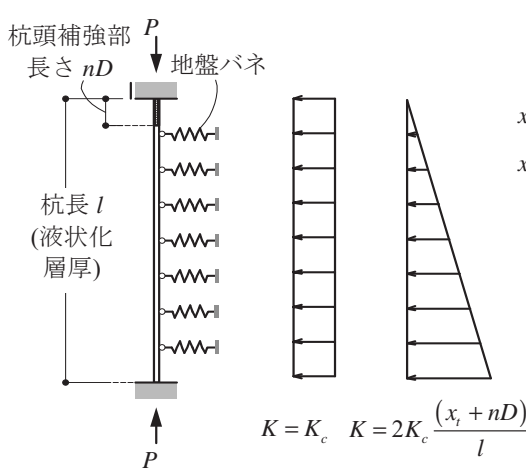

(a) 等分布 (b) 三角形 分布

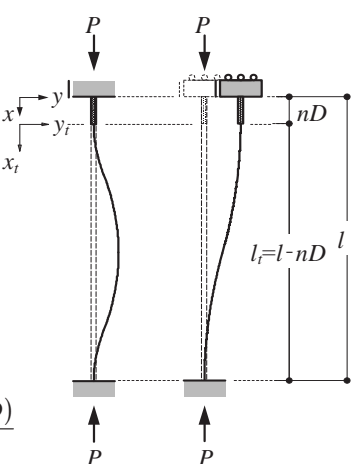

(a)

図 4 地盤反力係数分布モデル

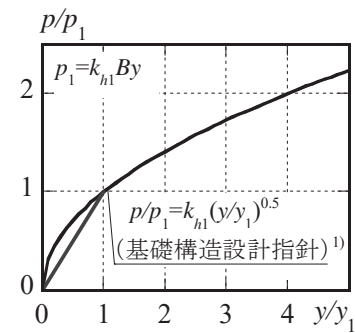

図 6 水平地盤反カー 水平変位関係
いる。杭長は実大スケールで $10.6 \mathrm{~m}$ であり, 地盤相対密度 D r は 30 , $60 \%$ 及び地盤無し（表 5 斜線部）である。

入力波は Case1 では sweep 波, Case2 では臨海波とし, 最大加速 度をそれぞれ $3.0 \mathrm{~m} / \mathrm{s}^{2}, 5.0 \mathrm{~m} / \mathrm{s}^{2}$ に基準化している。Case1では杭の動 座屈を確認するため, 試験体の固有周期を含む sweep 波を用いてお り, 加振開始から 50 秒間で周期を 2.0 秒から 0.3 秒まで変化させて いる。Case2 は基礎部の水平移動を許容した実際の杭・上屋構造物 を想定したモデルとし，設計時に用いられる人工地震波の臨海波を 入力している。臨海波の入力波の時刻歴（振動台で実測された加速 度）は図 2 に示寸通りである。図 3 に各々の一質点系の加速度応答 スペクトルを示す。参考までに板バネに載せた上屋構造物と板バネ の曲げ岡性から求めた上屋構造物の固有周期を次式に示す。

$$
\mathrm{T}=2 \pi \sqrt{\mathrm{m}_{1} / \mathrm{n}_{\mathrm{b}} \mathrm{k}} \quad \text { (1) } \quad \mathrm{k}=12 \mathrm{El} / \mathrm{h}^{3} \quad \text { (2) }
$$

ここで, $\mathrm{m}_{1}$ : 上屋構造物重量, $\mathrm{E}:$ 板バネのヤング率，I: 板バネの 断面二次モーメント, $\mathrm{n}_{\mathrm{b}}$ : 板バネの枚数, $\mathrm{h}$ : 図 1(e)に示す板バネ長 さである。Case1, Case2 シリーズの上屋構造物の固有周期は, それ ぞれ低層及び中層建築物を想定して実大スケールで 0.55 秒, 1.08 秒 としており, 図 3 中に文で示している。以下, 実大スケールで示す。

\section{2 数值解析の仮定条件}

3.2 3.3 節及び 4.2 節では有限要素解析により杭頭補強杭の曲げ座 屈性状を明らかにする。以下に数值解析において採用した仮定を示 す。なお，本論文の有限要素解析は Abaqus 6.14 を用いて行った。

\section{2. 1 軸力のみを受ける杭の弾性固有值解析の場合 (3.3 節)}

本論文では, 3.3 節の弾性固有值解析における仮定を, 文献 4)を 元に次のように設けている。

1) 杭は単杭とする。

2) 杭に作用する荷重は鉛直荷重のみとする。

3)杭頭補強部長さは図 4 のように長さ nD とし，この範囲を剛域と 仮定する。弾性曲げ座屈荷重式の誘導に際して, 剛域と仮定した 範囲外で座屈変形を生じるものとし, 図 5 に示寸杭頭補強部下端 を原点とした $\mathrm{x}_{\mathrm{t}}-\mathrm{y}_{\mathrm{t}}$ 座標により杭の変位関数を設定する。図中の $\mathrm{I}_{\mathrm{t}}$ は杭頭補強範囲が剛域となるときの杭の座屈長さ $(=1-n D)$ である。 4) 杭の境界条件は, 遠心載荷実験の支持条件を再現するため, 図 5 に示寸(a)両端固定支持, (b)杭頭固定ローラー下端固定支持と寸る。 5) 地盤反力係数分布は図 4(a)に示すように, 深度方向に(a)等分布, (b)三角形分布と寸る。液状化地盤では地盤が杭に対して水平抵抗 側となる場合と水平荷重側となる場合があるが，本論文では抵抗
側になるものと仮定する。なお，地盤が荷重側として作用する場 合については今後検討していく。

6) 液状化層は基礎部直下から下部の非液状化層までとし, その地盤 反力係数を図 4 のような水平変位に比例した反力をもつ弾性バネ に置換する。そして, 杭中央に作用する単位長さあたりの水平地 盤ばね定数 $K_{c}$ を次式で与える。

$$
\mathrm{K}_{\mathrm{c}}=\mathrm{k}_{\mathrm{h} 1} \mathrm{~B} \quad\left(\mathrm{MN} / \mathrm{m}^{2}\right) \quad \text { (3) } \quad \mathrm{k}_{\mathrm{hl}}=80 \mathrm{E}_{0} \overline{\mathrm{B}}^{-\frac{3}{4}}\left(\mathrm{MN} / \mathrm{m}^{3}\right) \quad \text { (4) }
$$

ここで， $k_{h 1}$ は文献 1)に示される水平地盤反力係数， $\bar{B}$ は文献 1) の無次元化杭径（杭径を $\mathrm{cm}$ で表した無次元化数值）であり, $\mathrm{E}_{0}$ は変形係数である。第 3 章の数值解析で用いる $\mathrm{K}_{\mathrm{c}}$ の值は, 文献 4) と同様, $0.01 \sim 1.0 \mathrm{MN} / \mathrm{m}^{2}$ とする。 $\mathrm{K}_{\mathrm{c}}=0.01 \mathrm{MN} / \mathrm{m}^{2}$ が地盤の有効応 力がほとんどない状態, $\mathrm{K}_{\mathrm{c}}=1.0 \mathrm{MN} / \mathrm{m}^{2}$ が杭の曲げ座屈を生じる上 限の水平地盤ば亦定数に相当する。

\section{2.2 軸力のみを受ける杭の弾塑性大変形解析の場合 (3.2 節)}

3.2 節の軸力のみを受ける杭頭補強鋼管杭の弾塑性大変形解析で は, 数值解析モデルを図 4 と同様とし, 2.2.1 項の仮定 1) 6)に次の 仮定を加える。

7)杭の幾何学的及び材料非線形性と, 地盤の非線形性を考慮する。 8) 杭の初期不整は, 文献 4)を参考に弾性固有值解析により得られた 1 次, 2 次モードを sine 関数で表し, 最大值を杭長の $0.05 \%$ とする。 9) 杭材(鋼)の材料特性は, 文献 12)の引張試験結果を元にモデル化し た Round House 型，中詰部材の材料特性は表 2 のアルミとする。 10) 地盤は建築基礎構造設計指針 ${ }^{1)}$ の設計式で示される非弾性地盤 とする。図 6 に, 文献 1)の水平地盤反力-水平変位関係を示す。

\section{2.3 軸力と水平力を受ける杭の弾塑性大変形解析の場合 (4.2 節)}

4.2 節の軸力と水平力を受ける杭頭補強鋼管杭の弾塑性解析モデ ルにおいては，2.2.1 及び 2.2.2 項の仮定 1)，3)，6)，7) 10)に加えて 次の仮定を設ける。

11) 杭の境界条件は図 5(b)の杭頭固定ローラー下端固定支持として, 杭頭の水平変形を許容する。

12) 地盤反力係数分布は図 4(b)の三角形分布とする。水平地盤ばね 定数 $K_{c}$ は, 文献 13)の知見を元に, 遠心載荷実験における地盤 相対密度 $\mathrm{Dr}=30 ， 60 \%$ から変形係数をそれぞれ $\mathrm{E}_{0}=3.50$, $3.85 \mathrm{MN} / \mathrm{m}^{2}$ として求め, 液状化時による低減係数 $\beta=0.1,0.2$ を乗 じ，これを(3)，(4)式に代入して算出する。

13) 杭頭の作用軸力 $N$ を一定とし, 水平力 $P$ のみを単調増加させる。 軸力比 $\mathrm{N} / \mathrm{N}_{\mathrm{y}}$ は試験体の初期軸力比 0.33 を含めて $0.1 \sim 0.5$ とする。 


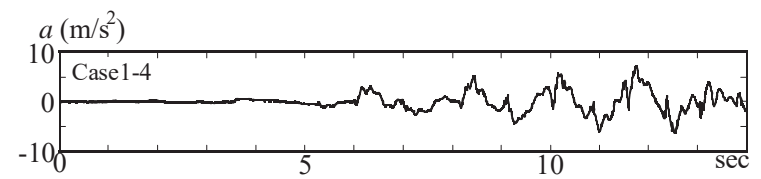

(a) 上屋構造物加速度応答時刻歴

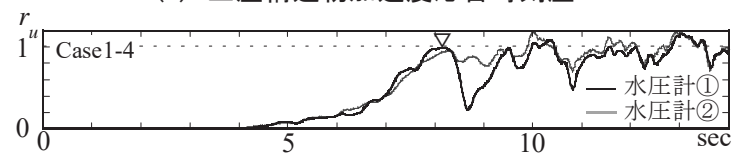

（b）過剩間隙水圧比応答時刻歴

$\mathrm{N}_{\mathrm{b}}\left(\times 10^{3} \mathrm{kN}\right)$

$\frac{-3.00 \mathrm{~N}_{\mathrm{y}}(=3921 \mathrm{kN})}{5}$

(c) 板バネより算出した杭の作用軸力応答時刻歴

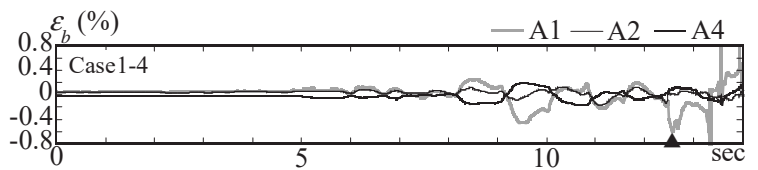

(d) 各杭の曲げ歪応答時刻歴

図 7 Case1-4における応答時刻歴

\section{3 、軸力のみが作用する場合の杭頭補強鋼管杭の動座屈挙動}

3.1 基礎部の水平変形を拘束した上屋·杭基礎一液状化地盤系の遠 心載荷実験

本節では，基礎部の水平変形を拘束し，杭に軸力のみが作用する ときの上屋・杭基礎一液状化地盤系の遠心載荷実験により，杭頭補 強杭の動座屈挙動を明らかにする。

\subsection{1 応答時刻歴}

図 7, 図 8 に地盤相対密度 $\mathrm{Dr}=30 \%$ の Case1 の実験結果, Case1-4 （杭頭補強無し）と Case1-5（補強部長さ1D）の応答時刻歴を示寸。

図 7(a), 図 8(a)は上屋構造物の加速度応答，(b)は過剩間隙水圧比応 答, (c)は杭の作用軸力応答, (d)は杭頭部近傍および杭中央の曲げ歪 応答の時刻歴である。(b)の過㮃間隙水圧比は, 地表から $3.4 \mathrm{~m}$ (水圧 計(1)， $5.8 \mathrm{~m}$ (水圧計(2)）の結果をそれぞれ黒線，灰色線で示す。 縦軸の過剩間隙水圧比 $r_{u}$ が上昇して $r_{u}=1$ となったときを液状化発生 $(\nabla)$ とする。(c)の杭の作用軸力 $\mathrm{N}_{\mathrm{b}}$ は, 板バネの軸歪により求められ る上屋構造物の自重及び転倒モーメントによる偶力の和を，各板バ ネを支持する 2 本の杭が負担するものとして, 次式より算出した ${ }^{7)}$ 。

$$
\mathrm{N}_{\mathrm{b}}=\frac{\varepsilon_{\mathrm{bxi}}+\varepsilon_{\text {byi }}}{2} \mathrm{EA}_{\mathrm{b}} / 2+\mathrm{m}_{2} \mathrm{~g} / 4
$$

ここで, $A_{b}$ : 板バネの断面積, $\varepsilon_{b x i}, \quad \varepsilon_{b y i}$ : 板バネの両側の歪值, $\mathrm{m}_{2}$ : 基礎部の重さである。板バネの軸歪は，最初に杭が動座屈を生じた 側の板バネで基礎部に近い歪ゲージ（図 1(e)中の X3 もしくは Y3） から算出したものである。いずれの試験体でも杭全体の動座屈発生 前までは, 板バネの軸歪は最大 $0.02 \%$ 以下, 動座屈発生後でも $0.05 \%$ 程度であり，板バネが弾性であることを確認している。軸力は圧縮 時を負，引張時を正で表す。また図 7(c), 図 8(c)中の $\triangle$ は動座屈発 生前までの杭の最大圧縮軸力を示す。なお，杭の降伏軸力 $\mathrm{N}_{\mathrm{y}}$ は $3921 \mathrm{kN}$ である。図 7(d), 図 8(d)は, 杭頭部近傍及び杭中央の曲げ歪 応答時刻歴である。図中の山（もしくは者）は，各 $0.1 \mathrm{sec}$ 間で曲げ 歪増分（傾き）が最大となるとき（曲げ歪増分最大時）を示す。曲 げ歪増分最大時とは，文献 7)において鋼管杭が曲げ座屈する時刻, すなわち杭の水平変形(曲げ変形)が急激に増大寸る時刻と定義した

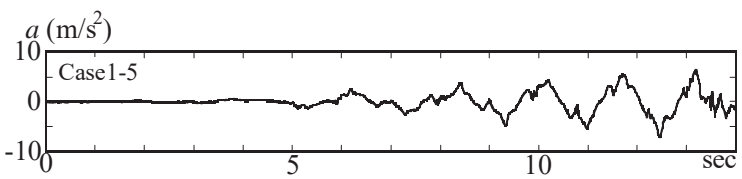

（a）上屋構造物加速度応答時刻歴

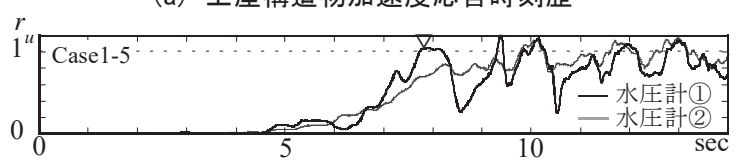

(b) 過剰間隙水圧比応答時刻歴



(c) 板バネより算出した杭の作用軸力応答時刻歴

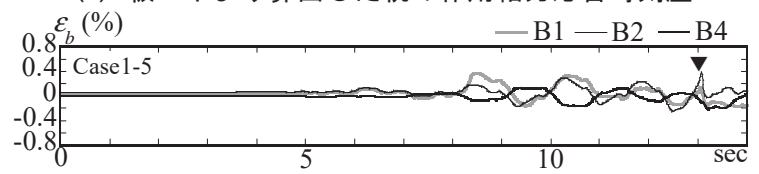

(d) 各杭の曲げ歪応答時刻歴

図 8 Case1-5における応答時刻歴

ものであり，本論文では杭の動座屈発生時刻とする。曲げ歪は，図 1(b)に示すように加振方向の杭前後面に貼付した歪ゲージ值の差の 半分の值 $\varepsilon_{\mathrm{bi}}=\left(\varepsilon_{\mathrm{pxi}}-\varepsilon_{\mathrm{pyy}}\right) / 2$ として求めている。最終的に上屋構造物が倒 れた側の直下の杭には, 動座屈直前までに最大作用圧縮軸力が生じ ていたことから，上屋が倒れた側の杭を選定し，杭頭部 $\mathrm{i}=1$ の結果 を灰色線, $i=2$ の結果を黒細線, 杭中央 $\mathrm{i}=4$ の結果を黒太線で示して いる。動座屈発生後は，すぐに上屋が倒壊防止用の拘束治具にぶつ かったため，それまでの結果を掲載している。

Case1-4（補強無し）では，加振開始 $(0 \mathrm{sec})$ 以降 $8 \mathrm{sec}$ 付近で $r_{\mathrm{u}}$ が 1 に達し, 液状化が発生した（図 7(b)の $\nabla) 。 12 \mathrm{sec}$ 付近で作用圧縮軸 力が最大圧縮軸力 $3270 \mathrm{kN}$ となり (図 $7(\mathrm{c})$ の), ほぼ同時に杭 A の $\mathrm{i}=1(\mathrm{~A} 1)$ で曲げ歪増分が最大となって動座屈を生じた（図 7(d)の $\boldsymbol{\nabla}$ )。

Case2-5（補強部長さ1D）では, Case2-4 と同様 8sec 付近で $r_{u}$ が 1 に達し，液状化が発生した（図 8(b)の $\nabla) 。 13 \mathrm{sec}$ 付近で作用圧縮軸 力が最大圧縮軸力 $3366 \mathrm{kN}$ となり (図 $8(\mathrm{c})$ の $\triangle$ ), ほぼ同時に杭 B の $\mathrm{i}=2(\mathrm{~B} 2)$ で曲げ歪増分が最大となって動座屈を生じた(図 8(d)の の)。

\section{1 .2 補強部長さによる最大軸力の違い}

表 4 に, 各試験体における杭の初期圧縮軸力 $\mathrm{N}_{0}$ 及び最大作用圧縮軸 力 $\mathrm{N}_{\mathrm{bmax}}$ と降伏軸力 $\mathrm{N}_{\mathrm{y}}$ との比を示す。地盤の有無によらず, 試験体の最 大圧縮軸力は杭頭補強部が長いほど上昇しており, 補強部を有する場合 の座屈荷重は, 補強無しの場合よりも $4 \%$ 程度上昇している。

\section{2 杭頭補強鋼管杭の弾塑性大変形解析}

本節では, 有限要素法による弾塑性大変形解析により杭頭補強部 長さが鋼管杭の弾塑性曲げ座屈性状に及ぼす影響を明らかにする。

図 9 に, 地盤反力係数分布が三角形分布, 図 6 の水平地盤反力一 水平変位関係を有する非弾性地盤で, 細長比 $\lambda=75(\mathrm{I}=10.4 \mathrm{~m})$ の場合の 杭の平均軸応力一平均軸歪関係を示す。縦軸は杭頭の鉛直荷重 $\mathrm{P}$ を

表 4 Case1 の初期圧縮軸力及び最大圧縮軸力

\begin{tabular}{|c|c|c|c|c|c|}
\hline 試験体名 & Case1-1 & Case1-2 & Case1-3 & Case1-4 & Case1-5 \\
\hline 初期軸力 $N_{0}(\mathrm{kN})$ & 1275 & 1275 & 1275 & 1275 & 1275 \\
(軸力比 $\left.\mathrm{N}_{0} / \mathrm{N}_{\mathrm{y}}\right)$ & $(0.33)$ & $(0.33)$ & $(0.33)$ & $(0.33)$ & $(0.33)$ \\
\hline 最大軸力 $\mathrm{N}_{\mathrm{bmax}}(\mathrm{kN})$ & 2928 & 3029 & 3064 & 3270 & 3366 \\
(軸力比 $\left.\mathrm{N}_{\text {bmax }} / \mathrm{N}_{\mathrm{y}}\right)$ & $(0.75)$ & $(0.77)$ & $(0.78)$ & $(0.83)$ & $(0.86)$ \\
\hline 補強部長さ $\mathrm{nD}$ & 0 & $1 \mathrm{D}$ & $3 \mathrm{D}$ & 0 & $1 \mathrm{D}$ \\
\hline
\end{tabular}


鋼管断面積 $\mathrm{A}$ で除した平均軸応力 $\sigma_{\mathrm{x}}$ であり, 横軸は杭頭の鉛直変位 を材長 | で除した平均軸歪 $\varepsilon_{\mathrm{x}}$ である。パラメータは杭頭補強の有無 と杭の材端支持条件である。水平地盤ばね定数 $\mathrm{K}_{\mathrm{c}}=0.1 \mathrm{MN} / \mathrm{m}^{2}$ で補強 部長さ $3 D$ の杭は弾性剛性が補強無しよりも $8 \%$ 程度上昇し, 最大軸 応力は両端固定支持で $2 \%$ 程度, 杭頭固定ローラー下端固定支持で $7 \%$ 程度上昇している。両端固定支持の場合, 杭頭の水平変形が拘束 され，座屈長さが短くなるため，補強の有無によらず軸応力度がほ ぼ降伏応力度に達している。一方, 杭頭固定ローラー下端固定支持 では最大軸応力に達した後急激に耐力低下しているが, 補強部長さ 3D の杭は補強無しの杭よりも耐力低下がやや緩やかになっている。

図 10 に補強部長さが異なる杭の弾塑性曲げ座屈応力度 $\sigma_{\mathrm{cr} 0}$ の比較 を示す。縦軸は, 水平地盤ばね定数 $\mathrm{K}_{\mathrm{c}}=0.01 \sim 1.0 \mathrm{MN} / \mathrm{m}^{2}$, 杭細長比 $\lambda=58 \sim 179(\mid=10 \sim 31 \mathrm{~m})$ における, 補強部長さ $1 \mathrm{D}$ 及び $3 \mathrm{D}$ の杭の数值解 析結果, 横軸は補強無しの杭の結果である。杭頭補強杭の弾塑性曲 げ座屈応力度は補強無しの場合より最大 $12 \%$ 程度上昇している。ま た図中には，表 4 に示した Case1 シリーズの最大軸力を灰色でプロ ットしている。数值解析結果及び遠心載荷実験結果より, 補強部長 さ3D の場合は $1 \mathrm{D}$ の場合よりも座屈耐力上昇効果が高くなっている。

\section{3 杭頭補強鋼管杭の弾性曲げ座屈荷重式}

本節ではエネルギー法による変分原理により, 杭頭補強鋼管杭が 地盤の水平変形拘束を受けるときの弾性曲げ座屈荷重式を誘導する。

地盤の水平変形拘束を受ける杭頭補強鋼管杭が曲げ座屈するとき のポテンシャルエネルギー式は, 文献 4)より次式となる。

$U=\int_{0}^{l_{t}}\left(E_{s} I_{s} u^{\prime \prime 2}-P u^{\prime 2}+K u^{2}\right) d x_{t}$

ここで, $E_{s} s_{s}$ は鋼管杭の曲げ岡性, $P$ は鉛直荷重, $K$ は地盤水平ば 水定数の深度方向の関数, u は座屈変形である。u の変位関数に 3 つ以上の未定係数を有する sine 関数を用いることで高次モードまで 対応した座屈荷重を定式化できるが， $3 \times 3$ 以上の行列式が 0 となる 条件を適用寸ることになり，陽な形で表せないことから，1つもし

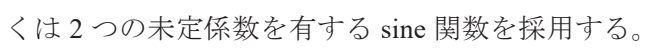

(a) 両端固定支持の場合

両端固定支持の場合, 図 4(a), (b)の地盤反力係数分布における座 屈変形 $\mathrm{u}$ を簡便な関数として次のように仮定する。

$$
\mathrm{u}=\mathrm{a}\left(1-\cos \frac{2 \pi \mathrm{x}_{\mathrm{t}}}{\mathrm{I}_{\mathrm{t}}}\right)
$$

ここで a は未定係数である。(7)式を(6)式に代入し，(6)式をa で偏 微分して, 釣合方程式を求めると弾性曲げ座屈荷重式は次式となる。

\section{(i) 等分布}

$$
\mathrm{P}_{\mathrm{cr}}=\mathrm{E}_{\mathrm{s}} \mathrm{I}_{\mathrm{s}}\left(\frac{\pi}{\mathrm{I}_{\mathrm{t}}}\right)^{2}\left[4+\frac{3}{4}\left(\frac{\mathrm{I}_{\mathrm{t}}}{\pi}\right)^{4} \frac{\mathrm{K}_{\mathrm{c}}}{\mathrm{E}_{\mathrm{s}} \mathrm{I}_{\mathrm{s}}}\right] \quad\left(\mathrm{I}_{\mathrm{t}}<2 \pi \sqrt[4]{\mathrm{E}_{\mathrm{s}} \mathrm{I}_{\mathrm{s}} / 3 \mathrm{~K}_{\mathrm{c}}}\right)
$$

(ii) 三角形分布


ただし，(8)，(9)式は 1 次モードが卓越する場合であり, 杭の細長比 入が小さい場合を対象としている。(8), (9)式右に示す範囲外では, 文献 4)7)の杭頭補強されていない場合の知見を参考にして, (8), (9) 式の極小值を通り, 細長比 $\lambda$ が無限大になるとき, 水平変形拘束を 受ける単純支持の場合の弾性曲げ座屈荷重に収束する以下の (10), (11)式を用いて, 弾性曲げ座屈荷重を近似する。

(i) 等分布

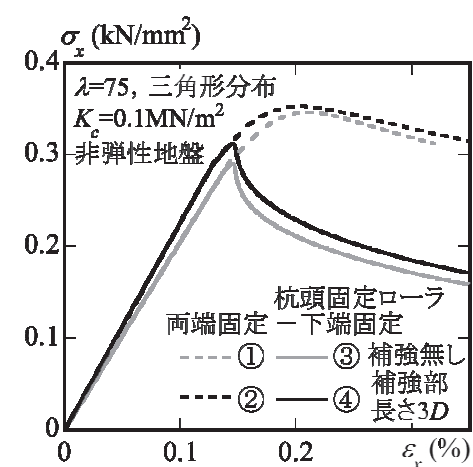

図 9 鋼管杭平均軸応力ー 平均軸歪関係

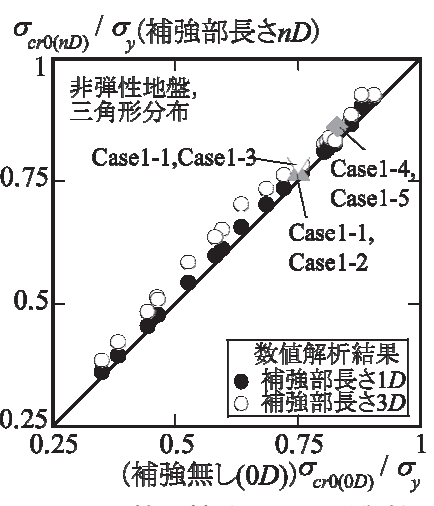

図 10 杭頭補強による弾塑性 曲げ座屈耐力上昇効果

$$
\mathrm{P}_{\mathrm{cr}}=\mathrm{E}_{\mathrm{s}} \mathrm{I}_{\mathrm{s}}\left(\frac{\pi}{\mathrm{I}_{\mathrm{t}}}\right)^{2}\left[8\left(1-\frac{1}{\sqrt{3}}\right)+2\left(\frac{\mathrm{I}_{\mathrm{t}}}{\pi}\right)^{2} \sqrt{\frac{\mathrm{K}_{\mathrm{c}}}{\mathrm{E}_{\mathrm{s}} \mathrm{I}_{\mathrm{s}}}}\right] \quad\left(\mathrm{I}_{\mathrm{t}} \geq 2 \pi \sqrt[4]{\mathrm{E}_{\mathrm{s}} \mathrm{I}_{\mathrm{s}} / 3 \mathrm{~K}_{\mathrm{c}}}\right)
$$

(ii) 三角形分布

$$
\begin{aligned}
& P_{c r}=E_{s} I_{s}\left(\frac{\pi}{I_{t}}\right)^{2}\left[8\left(1-\frac{1}{\sqrt{3}}\right)+2\left(\frac{I_{t}}{\pi}\right)^{2} \sqrt{\frac{K_{c}}{E_{s} I_{s}}}\right] {\left[\frac{3}{4}+\frac{1}{2}\left(\frac{\pi}{I_{t}}\right)^{2} \sqrt{\frac{E_{s} I_{s}}{K_{c}}}\right]\left[1+\frac{n D}{\mathrm{I}}\right] } \\
&\left(I_{t} \geq 2 \pi \sqrt[4]{E_{s} I_{s} / 3 K_{c}}, n \leq 3\right)(11)
\end{aligned}
$$

(b) 杭頭固定ローラー下端固定支持

杭頭固定ローラー下端固定支持の場合, 図 4(a), (b)の地盤反力係 数分布における座屈変形 $\mathrm{u}$ を次式のように仮定する。

$$
u=a\left(1+\cos \frac{\pi x_{t}}{I_{t}}\right)+b\left(1-\cos \frac{2 \pi x_{t}}{I_{t}}\right)
$$

ここで $a, b$ は未定係数である。(12)式を(6)式に代入して, (6)式を $a$,

bで偏微分し, 釣合方程式を求めると座屈荷重式は次式となる。

(i) 等分布

$$
\begin{aligned}
& P_{c r}=\frac{5}{8}\left[4 E_{s} I_{s}\left(\frac{\pi}{I_{t}}\right)^{2}+3 K_{c}\left(\frac{I_{t}}{\pi}\right)^{2}\right]-\frac{1}{8} \sqrt{25\left\{4 E_{s} I_{s}\left(\frac{\pi}{I_{t}}\right)^{2}+3 K_{c}\left(\frac{I_{t}}{\pi}\right)^{2}\right\}^{2}-16 X_{1}} \\
& \quad\left(I_{t}<1.75 \pi \sqrt[4]{E_{s} I_{s} / K_{c}}\right) \\
& X_{1}=16 E_{s}{ }^{2} I_{s}{ }^{2}\left(\frac{\pi}{I_{t}}\right)^{4}+51 E_{s} I_{s} K_{c}+5 K_{c}{ }^{2}\left(\frac{I_{t}}{\pi}\right)^{4}
\end{aligned}
$$

(ii) 三角形分布

$$
\begin{aligned}
P_{\mathrm{cr}} & =\frac{1}{8}\left[20 \mathrm{E}_{\mathrm{s}} \mathrm{I}_{\mathrm{s}}\left(\frac{\pi}{\mathrm{I}_{\mathrm{t}}}\right)^{2}+\frac{\mathrm{K}_{\mathrm{c}}}{\mathrm{I}}\left(\frac{\mathrm{I}_{\mathrm{t}}}{\pi}\right)^{2}\left\{15(\mathrm{I}+\mathrm{nD})-\frac{64}{\pi}\left(\frac{\mathrm{I}_{\mathrm{t}}}{\pi}\right)\right\}\right] \\
& -\frac{1}{8} \sqrt{\left\{20 \mathrm{E}_{\mathrm{s}} \mathrm{I}_{\mathrm{s}}\left(\frac{\pi}{\mathrm{I}_{\mathrm{t}}}\right)^{2}+\frac{\mathrm{K}_{\mathrm{c}}}{\mathrm{I}}\left(\frac{\mathrm{I}_{\mathrm{t}}}{\pi}\right)^{2}\left\{15(\mathrm{I}+\mathrm{nD})-\frac{64}{\pi}\left(\frac{\mathrm{I}_{\mathrm{t}}}{\pi}\right)\right\}\right\}^{2}-16 \mathrm{X}_{2}}
\end{aligned}
$$$$
\left(\mathrm{I}_{\mathrm{t}}<1.96 \pi \sqrt[4]{\mathrm{E}_{\mathrm{s}} \mathrm{I}_{\mathrm{s}} / \mathrm{K}_{\mathrm{c}}}\right)
$$

$$
\begin{aligned}
& \mathrm{X}_{2}=16 \mathrm{E}_{\mathrm{s}}{ }^{2} \mathrm{I}_{\mathrm{s}}{ }^{2}\left(\frac{\pi}{\mathrm{I}_{\mathrm{t}}}\right)^{4}+\frac{\mathrm{K}_{\mathrm{c}}}{\mathrm{l}} \mathrm{E}_{\mathrm{s}} \mathrm{I}_{\mathrm{s}}\left\{51(\mathrm{I}+\mathrm{nD})-\frac{256}{\pi}\left(\frac{\mathrm{I}_{\mathrm{t}}}{\pi}\right)\right\} \\
& +\frac{K_{c}{ }^{2}}{I^{2}}\left(\frac{I_{t}}{\pi}\right)^{4}\left\{5(I+n D)^{2}-\frac{304}{9 \pi^{2}}\left(I^{2}-n^{2} D^{2}\right)-\frac{1024}{81 \pi^{2}}\left(\frac{I_{t}}{\pi}\right)^{2}\right\}
\end{aligned}
$$

(a) と同様, 上式右に示寸範囲外については, 文献 5)6)の知見を元 に(13)，(14)式の極小值を通る，簡便で実用的な近似式を提示する。 (i) 等分布

$$
P_{c r}=\sqrt{5\left(1+\frac{n D}{l}\right) E_{s} I_{s} K_{c}} \quad\left(I_{t} \geq 1.75 \pi \sqrt[4]{E_{s} I_{s} / K_{c}}\right)
$$

(ii) 三角形分布

$$
P_{c r}=E_{s} I_{s}\left(\frac{\pi}{I_{t}}\right)^{2}\left[\frac{6}{5}+\frac{7}{6}\left(1+3 \frac{n D}{I}\right)\left(\frac{I_{t}}{\pi}\right)^{2} \sqrt{\frac{K_{c}}{E_{s} I_{s}}}\right] \quad\left(I_{t} \geq 1.96 \pi \sqrt[4]{E_{s} I_{s} / K_{c}}\right)
$$

図 11 にエネルギー法及び弾性固有值解析から求めた弾性曲げ座 屈応力度と細長比の関係を示す。縦軸は弾性曲げ座屈荷重 $\mathrm{P}_{\mathrm{cr}}$ を杭 
の断面積 $\mathrm{A}$ で除した弾性曲げ座屈応力度 $\sigma_{\mathrm{cr}}$, 横軸は杭の細長比 $\lambda(=/ \mathrm{i})$ である。三角形分布, 水平地盤ば䀅定数 $\mathrm{K}_{\mathrm{c}}=0.01,0.1,1.0 \mathrm{MN} / \mathrm{m}^{2}$, 杭頭固定ローラー下端固定支持条件において, 点線は補強部長さ $3 \mathrm{D}$ の場合の弾性曲げ座屈荷重式(14a), (14b)式, プロットは細長比 $\lambda=58 \sim 179(\mathrm{l}=10 \sim 31 \mathrm{~m})$ における弾性固有值解析結果を示している。 $\mathrm{K}_{\mathrm{c}}=0.01,0.1 \mathrm{MN} / \mathrm{m}^{2}$ の水平地盤ばね定数において, 細長比 $\lambda$ の大きい 範囲 $(\lambda=121 \sim 179)$ では数值解析結果は概ね(14a), (14b)式の座屈荷重 に概ね一致しているが, $\lambda$ 小さい範囲 $(\lambda=58 \sim 104)$ の数值解析結果は (14a), (14b)式よりも $12 \%$ 程度小さくなっている。これは, 細長比が 小さくなると, 剛域と仮定した補強部の曲げ抵抗 $\left(E_{a} l_{a}+E_{s} l_{s}\right) / n D\left(E_{a} l_{a}\right.$ : 中詰部材の曲代剛性）が杭の曲げ抵抗 $E_{s} I_{s} / l$ に対して相対的に小さ くなるためである。そこで本論文では，本来有限な曲げ剛性を有す る杭頭補強部について, その拘束効果を長さ n'D の剛域として等価 に置き換えるため，鋼管の曲げ剛性に対する中詰部材の曲げ剛性の 比を用い, 後述の図 12 の数值解析結果に対応するように求めた次式 の等価補強部長さ係数 $n^{\prime}$ を提示する。

$$
n^{\prime}=\sqrt{\frac{1}{5} \cdot \frac{E_{a} I_{a}}{E_{s} I_{s}}} \cdot n\left(E_{a} l_{a}<5 E_{s} I_{s}\right) \quad(17 a) \quad n^{\prime}=n \quad\left(E_{a} l_{a} \geq 5 E_{s} I_{s}\right)
$$

なお，本論文の対象範囲（補強部長さ $3 \mathrm{D}$ 以下）において杭頭補強 されていない, すなわち $\mathrm{E}_{\mathrm{a}} \mathrm{l}_{\mathrm{a}}=0$ の場合, $\mathrm{n}^{\prime}=0$ となる。また, $\mathrm{E}_{\mathrm{a}} \mathrm{l}_{\mathrm{a}}=5 \mathrm{E}_{\mathrm{s}} \mathrm{I}_{\mathrm{s}}$ の場合 $n^{\prime}=n$ となることから， $E_{a} l_{a} \geqq 5 E_{s} l_{s}$ では補強部全長を剛域とみ なすこととする。図 11 に示すように, $\mathrm{K}_{\mathrm{c}}=0.01,0.1 \mathrm{MN} / \mathrm{m}^{2}$ の場合, 解析範囲である $\lambda \leqq 179$ では(17)式を適用した(14)式が数值解析結果 と概ね対応している。 $\mathrm{K}_{\mathrm{c}}=1.0 \mathrm{MN} / \mathrm{m}^{2}$ の場合は, (14)式の極小值とな る $\lambda=121$ 以下では(17)式を適用した(14)式が， $\lambda=121$ を超える範囲で は(17)式を適用した(16)式が概小対応している。

図 12 に, 杭頭固定ローラー下端固定支持, 三角形分布, 水平地盤 ば衩定数 $\mathrm{K}_{\mathrm{c}}=0.1 \mathrm{MN} / \mathrm{m}^{2}$ における, 杭頭補強部長さ係数 $\mathrm{n}$ と弾性曲 げ 座屈荷重上昇率ての比較を示す。各プロットは図 11 の弾性固有值解 析結果であり, 各線は(14a), (14b)式の弾性曲げ座屈荷重式から算出 される, 補強無しの場合に対する座屈荷重上昇率である。(14a), (14b) 式から求めた弾性座屈荷重上昇率（灰色線）は補強部長さ $\mathrm{n}$ に対し て数值解析結果を上回っている一方，(17)式の n'を適用した(14a), (14b)式による上昇率（図 12 の黒線）は，nに対して数值解析結果と

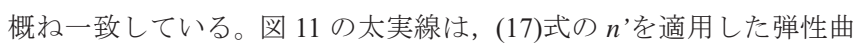
げ座屈応力度(14a), (14b)及び(16)式である。(17)式の $\mathrm{n}^{\prime}$ を適用した 弾性曲げ座屈応力度は数值解析結果と概小一致している。なお, 地 盤反力係数分布が等分布の場合の弾性曲げ座屈荷重(13a), (13b), (15) 式，また両端固定支持条件の弾性曲げ座屈荷重(8) (11)式も(17)式を 適用することで, 数值解析結果と概ね一致することを確認している。

\section{4 杭頭補強鋼管杭の弾塑性曲げ座屈耐力評価}

本節では, 3.3 節で誘導した弾性曲げ座屈荷重を適用した修正一 般化細長比による座屈曲線 ${ }^{9110}$ により，3.1 節及び 3.2 節での軸力の みを受ける杭頭補強鋼管杭の曲げ座屈耐力評価を試みる。

図 13 に, 3.1 節の Case1-1 Case1-5 の動座屈耐力（最大軸力）, 及 び 3.2 節の弾塑性曲げ座屈耐力と, 鋼構造設計規準 ${ }^{10)}$ (以降, 設計 規準と呼ぶ）及び限界状態設計指針 ${ }^{9}$ の設計式における座屈曲線と の比較を示す。縦軸は動座屈耐力 $\mathrm{N}_{\mathrm{bmax}}$ 及び弾塑性曲げ座屈耐力 $\mathrm{N}_{\mathrm{cr}}$ を降伏耐力 $\mathrm{N}_{\mathrm{y}}$ で除したものであり, 横軸は一般化細長比瓜である。 $\lambda_{c}$ は弾性曲げ座屈荷重 $\mathrm{P}_{\mathrm{cr}}((17)$ 式を適用した(8) (11)式及び(13) (16)

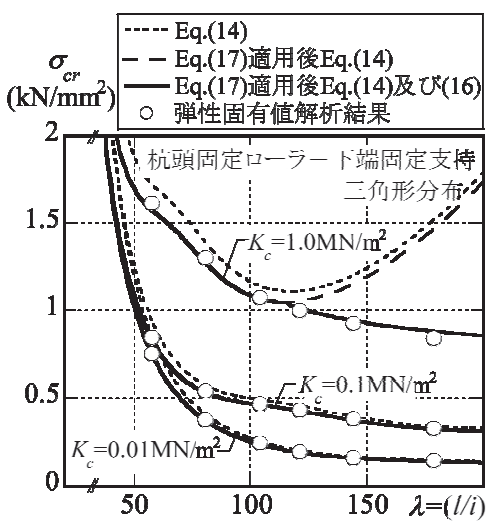

図 11 地盤反力係数分布の異なる 鋼管杭の弾性曲げ座屈応力度 (補強部長さ 3D)

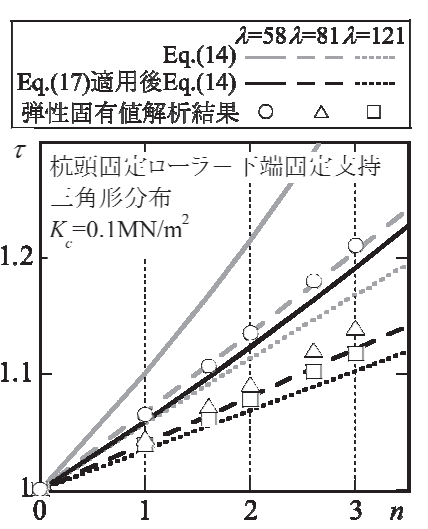

図 12 弾性座屈荷重上昇度 一補強部長さ係数関係

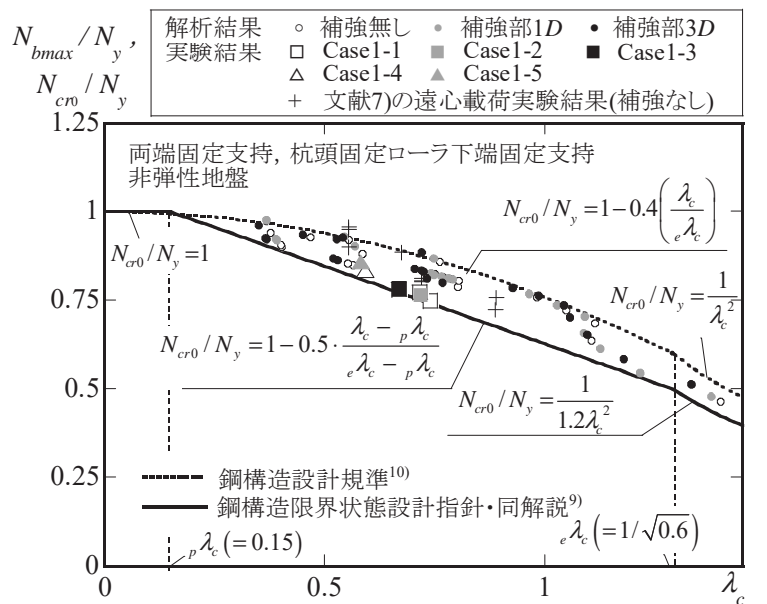

図 13 弾塑性曲げ座屈応力度と設計式の比較

式）に対する降伏耐力 $\mathrm{N}_{\mathrm{y}}$ の割合として次式で表される。

$$
\lambda_{\mathrm{t}}=\sqrt{\mathrm{N}_{\mathrm{y}} / \mathrm{P}_{\mathrm{cr}}}
$$

本論文では文献 4) 6)に従い, 非弾性地盤の場合は(8) (11)式及び (13) (16)式中の水平地盤ばね定数 $K_{c}$ を低減している。なお, 本数值 解析における $K_{c}$ は2 2.2 項より $0.01 \sim 1.0 \mathrm{MN} / \mathrm{m}^{2}$ である。実験試験体に ついては, 2.2 節の仮定 12)に基づき, $D r=30 \%$ （液状化による低減 率 $\beta=0.1 ）$ のとき $\mathrm{K}_{\mathrm{c}}=0.488 \mathrm{MN} / \mathrm{m}^{2}, \quad \mathrm{Dr}=60 \% \quad(\beta=0.2)$ のとき $\mathrm{K}_{\mathrm{c}}=1.074 \mathrm{MN} / \mathrm{m}^{2}$ となる。試験体の $\mathrm{K}_{\mathrm{c}}$ より $\lambda_{\mathrm{c}}$ を求めると, 基礎部固定 で杭頭補強無し $(n=0)$ のとき, それぞれ $\lambda_{c}=0.59,0.52$ となる。地 盤無し $\left(\mathrm{K}_{\mathrm{c}}=0 \mathrm{MN} / \mathrm{m}^{2}\right)$ の場合は $\lambda_{\mathrm{c}}=0.74$ であることから, 地盤の水平 拘束効果により， $\lambda_{c}$ がそれぞれ $20 \% ， 30 \%$ 程度小さくなっている。 また以下に, 図 13 中の座屈曲線である設計規準 ${ }^{10)}$ 及び限界状態設 計指針 ${ }^{9)}$ の設計式を示す。

鋼構造設計規準 ${ }^{10)}$ :

$$
\begin{array}{ll}
\mathrm{N}_{\text {cr } 0}=\left[1-0.4\left(\lambda_{\mathrm{c}} / \mathrm{e} \lambda_{\mathrm{c}}\right)\right] \cdot \mathrm{N}_{\mathrm{y}} & \left(\lambda_{\mathrm{c}} \leq_{\mathrm{e}} \lambda_{\mathrm{c}}\right)(19 \mathrm{a})^{\text {文献 10)5.3)式 }} \\
\mathrm{N}_{c r 0}=\frac{1}{\lambda_{\mathrm{c}}^{2}} \cdot \mathrm{N}_{\mathrm{y}} & \left(\mathrm{e} \lambda_{\mathrm{c}}<\lambda_{\mathrm{c}}\right)(19 \mathrm{~b})^{\text {文献 10)5.4)式 }}
\end{array}
$$

鋼構造限界状態設計指針 ${ }^{9)}$ ：

$$
\begin{aligned}
& \mathrm{N}_{\mathrm{cr} 0}=\mathrm{N}_{\mathrm{y}} \\
& \left(\lambda_{\mathrm{c}} \leq_{\mathrm{p}} \lambda_{\mathrm{c}}=0.15\right) \quad(20 \mathrm{a})^{\text {文献 9)3.2.a)式 }} \\
& \mathrm{N}_{c r 0}=\left(1-0.5 \cdot \frac{\lambda_{c}-{ }_{p} \lambda_{c}}{{ }_{e} \lambda_{c}-{ }_{p} \lambda_{c}}\right) N_{y}\left({ }_{p} \lambda_{c}<\lambda_{c} \leq{ }_{e} \lambda_{c}=1 / \sqrt{0.6}\right) \quad(20 b)^{\text {文献 9)3.2.b)式 }} \\
& \mathrm{N}_{\mathrm{c}}=\frac{1}{1.2 \lambda_{\mathrm{c}}^{2}} \cdot \mathrm{N}_{\mathrm{y}} \\
& \left({ }_{e} \lambda_{c}<\lambda_{c}\right)(20 c)^{\text {文献 9)3.2.c)式 }}
\end{aligned}
$$


ここで ${ }_{\mathrm{e}} \lambda_{\mathrm{c}}$ は弾性限界細長比， p $\lambda_{\mathrm{c}}$ は塑性限界細長比である。

図 13 において, Case1 シリーズの遠心載荷実験結果及び数值解析 結果は，概ね限界状態設計指針 ${ }^{9}$ の設計式を下限值として上回って おり，設計規準 ${ }^{10)}$ の設計式に対応している。液状化地盤における杭 頭補強鋼管杭の曲げ座屈耐力も(18)式を用いることで，通常の圧縮 材と同様，座屈耐力の下限值として限界状態設計指針 ${ }^{9}$ の設計式を 準用できる。したがって，次章以降，軸力と水平力を受ける杭の耐 力評価に $\mathrm{N}_{\mathrm{cr} 0}$ を適用する際，杭の弾塑性曲げ座屈耐力を安全側に評 価するために限界状態設計指針 ${ }^{9)}$ の座屈曲線を用いることとする。

例えば補強部長さ $3 \mathrm{D}$ の Case1-3 $\left(\mathrm{K}_{\mathrm{c}}=0 \mathrm{MN} / \mathrm{m}^{2}\right)$ の場合, 弾性座屈 荷重 $P_{\mathrm{cr}}$ が(9)式より Case1-1 の 1.23 倍となり,(18)式の一般化細長比 入 は Case1-1 では 0.74, Case1-3 では0.67 となる。これらを(20b)式 に代入して得られる弾塑性座屈耐力 $\mathrm{N}_{\mathrm{cr} 0} / \mathrm{N}_{\mathrm{y}}$ はそれぞれ $0.741,0.777$ となり, $n=0$ に対する $n=3$ の弾塑性座屈耐力上昇率は $4.8 \%$ となるこ とから，3.1.2 項の実験結果の 4\%程度と概敉しいことが分かる。

4. 軸力と水平力が作用する場合の杭頭補強鋼管杭の終局耐力評価

4.1 基礎部の水平変形を許容した上屋·杭基礎一液状化地盤系の遠 心載荷実験

本節では，基礎部の水平変形を許容し，杭に軸力と水平力が作用 する場合の上屋・杭基礎一地盤系の遠心載荷実験により，杭頭補強 鋼管杭の動的終局挙動を明らかにする。

\subsection{1 応答時刻歴}

図 14, 図 15 に地盤相対密度 $\mathrm{Dr}=30 \%$ の Case2 の実験結果, Case2-1 (補強無し), Case2-2（補強部長さ1D）の応答時刻歴を示す。(a), (b)は上屋構造物の水平加速度及び水平変位応答, (c) は過剩間隙水圧 比応答，(d)は杭の作用軸力応答の時刻歴である。(e) は各試験体の杭 頭部近傍 $\mathrm{i}=1,2$ の曲げ歪応答の時刻歴であり, $i=1$ の結果を灰色線,

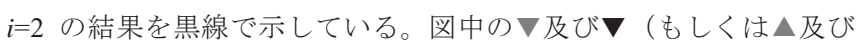

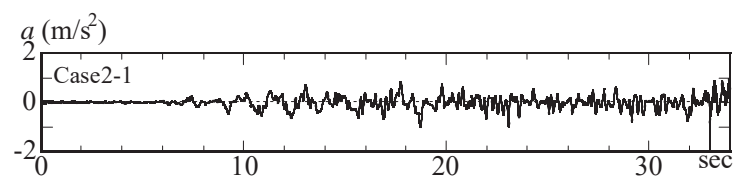

（a）上屋構造物加速度応答時刻歴

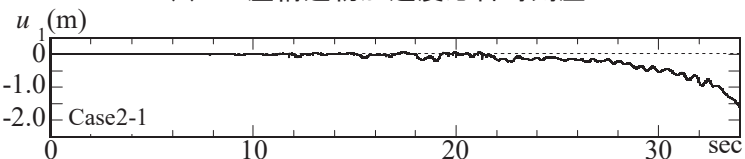

（b）上屋構造物水平変位応答時刻歴

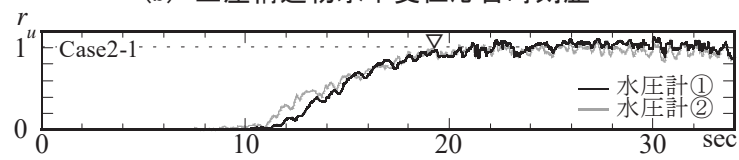

（c）過剩間隙水圧比応答時刻歴

$\mathrm{N}_{\mathrm{b}}\left(\times 10^{3} \mathrm{kN}\right)$

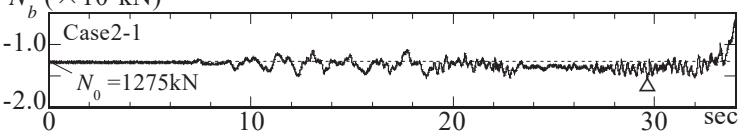

(d) 板バネより算出した杭の作用軸力応答時刻歴

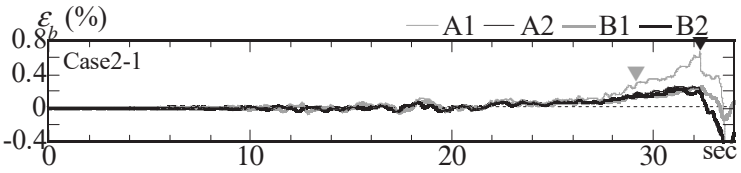

(e) 各杭の杭頭部近傍曲げ歪応答時刻歴 図 14 Case2-1における応答時刻歴
ム）は, 曲げ歪が片振りしている範囲で, 各 $0.1 \mathrm{sec}$ 間で曲げ歪増分 (傾き) が最大となる時刻（曲げ歪増分最大時）及び最大曲げ歪と なる時刻（最大曲げ歪時）を示している。Case2-4, Case2-5 以外の Case2 試験体は, 最終的に杭基礎全体が傾いて上屋構造物が倒壊防 止用の拘束治具にぶつかっており,この状態を以後終局状態と呼ぶ。

各応答時刻歴について, 補強無しの Case2-1 では過剩間隙水圧比 $\mathrm{r}_{\mathrm{u}}$ が 1 に達した $19 \mathrm{sec}$ (図 14(c)の $\nabla$ ) 以降, 上屋構造物の水平変位 が負側（杭 A, C 側）に片寄っている（図 14(b)）。杭の曲げ歪は $\mathrm{r}_{\mathrm{u}}=1$ に達した後徐々に増加していき, 29sec で杭 A の杭頭部 $\mathrm{i}=1$ (A1)の曲 げ歪増分が最大となり (図 $14(\mathrm{e})$ の) , 32sec で A1 の曲げ歪が $0.66 \%$ と最大となっている (図 $14(\mathrm{e})$ の $\boldsymbol{\nabla}$ )。最大曲げ歪時の上屋構造物水 平変位は $0.83 \mathrm{~m}$ である。この後杭基礎全体が傾き, 上屋構造物は倒 壊防止用の拘束治具にぶつかった。板バネから求めた杭の作用圧縮 軸力が最大となる時刻は 29sec 付近（図 14(d)の $\triangle$ ）であり, A1の 曲げ歪増分最大時とほぼ同時刻となった。最大変動圧縮軸力は $257 \mathrm{kN}$ で，初期圧縮軸力の $20 \%$ あるあ。

杭頭補強部長さ1D の Case2-2 では, r $\mathrm{r}_{\mathrm{u}}$ が 1 に達した $18 \mathrm{sec}$ 以降 (図 $15(\mathrm{c}) \nabla)$, 上屋構造物の水平変位が正側（杭 B, D 側）に片寄ってい る(図 15(b))。杭の曲げ歪は $r_{u}=1$ に達した後, 徐々に増加していき, $32 \mathrm{sec}$ で杭 B の非補強部上端 $\mathrm{i}=2(\mathrm{~B} 2)$ の曲げ歪増分が最大となり（図 $15(\mathrm{e})$ の )，42sec で B2 の曲げ歪が 0.70\%と最大となった（図 15(e) の文)。また杭 A では, i=2(A2)の曲げ歪が B2 の最大曲げ歪時より $0.5 \mathrm{sec}$ 遅れて, 曲げ歪 $0.70 \%$ となった。なお, 杭 B の $\mathrm{i}=2(\mathrm{~B} 2)$ 最大曲 げ歪時の上屋構造物水平変位は $0.87 \mathrm{~m}$ である。杭の作用圧縮軸力が 最大となる時刻は $29 \mathrm{sec}$ 付近 (図 $15(\mathrm{~d})$ の) であり, 最大変動圧縮 軸力は $250 \mathrm{kN}$ (初期圧縮軸力の $19.6 \%$ ）と Case2-1 とほぼ等しい。

また, 杭頭補強部長さ 3D の Case2-3 は, Case2-2 と同様, 地盤液 状化後に曲げ歪が増大し, 杭 A の非補強部上端 $\mathrm{i}=2(\mathrm{~A} 2)$ の曲げ歪が 最大となって終局状態に至った。地盤相対密度 $\mathrm{Dr} r=60 \%$ の Case2-4

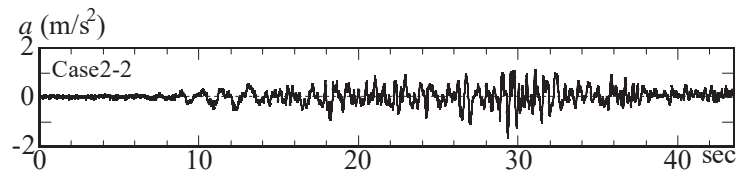

（a）上屋構造物加速度応答時刻歴

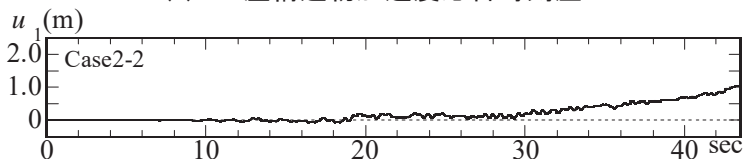

（b）上屋構造物水平変位応答時刻歴

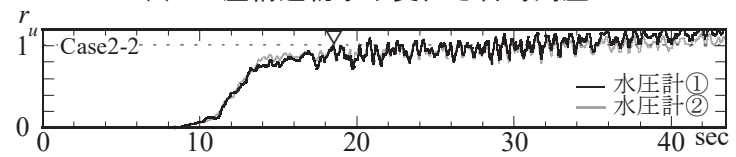

（c）過剰間隙水圧比応答時刻歴

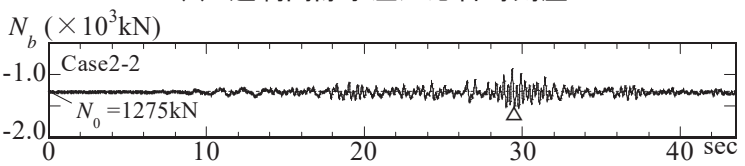

(d) 板バネより算出した杭の作用軸力応答時刻歴

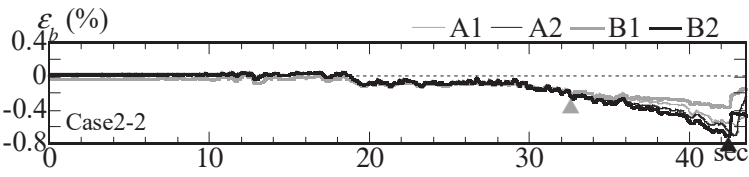

(e) 各杭の杭頭部近傍曲げ歪応答時刻歴

図 15 Case2-2における応答時刻歴 
表 5 Case2 シリーズにおける最大圧縮軸力及び最大曲げ歪

\begin{tabular}{|c|c|c|c|c|c|c|}
\hline \multicolumn{2}{|c|}{ 試験体名 } & Case2-1 & Case2-2 & Case2-3 & Case2-4 & Case2-5 \\
\hline \multicolumn{2}{|c|}{$\begin{array}{l}\text { 初期軸力 } N_{0}(\mathrm{kN}) \\
\left(\text { 軸力比 } \mathrm{N}_{0} / \mathrm{N}_{\mathrm{y}}\right)\end{array}$} & $\begin{array}{l}1275 \\
(0.33)\end{array}$ & $\begin{array}{l}1275 \\
(0.33)\end{array}$ & $\begin{array}{c}1275 \\
(0.33)\end{array}$ & $\begin{array}{l}1275 \\
(0.33)\end{array}$ & $\begin{array}{l}1275 \\
(0.33)\end{array}$ \\
\hline \multicolumn{2}{|c|}{$\begin{array}{c}\text { 最大軸力 } N_{b \max }(\mathrm{kN}) \\
\left(\text { 軸力比 } N_{b \max } / N_{\mathrm{y}}\right)\end{array}$} & $\begin{array}{c}1534 \\
(0.39) \\
\end{array}$ & $\begin{array}{l}1525 \\
(0.39) \\
\end{array}$ & $\begin{array}{c}1511 \\
(0.39) \\
\end{array}$ & $\begin{array}{c}1698 \\
(0.43) \\
\end{array}$ & $\begin{array}{c}1453 \\
(0.37) \\
\end{array}$ \\
\hline \multicolumn{2}{|c|}{ 補強部長さnD } & 0 & $1 \mathrm{D}$ & $3 \mathrm{D}$ & 0 & $1 \mathrm{D}$ \\
\hline \multicolumn{2}{|c|}{ 最大曲げ歪位置 } & $\mathrm{A} 1$ & B2 & $(\mathrm{C} 2)$ & A1 & $\mathrm{C} 2$ \\
\hline \multirow{2}{*}{$\begin{array}{c}\text { 最大曲げ歪 } \\
\varepsilon_{\mathrm{b}, \max }(\%) \\
\end{array}$} & $\mathrm{i}=1$ & 0.66 & 0.36 & $(0.11)$ & 0.19 & 0.10 \\
\hline & $\mathrm{i}=2$ & 0.26 & 0.70 & $(0.39)$ & 0.13 & 0.14 \\
\hline \multirow{2}{*}{$\begin{array}{c}\text { 最大圧縮軸歪 } \\
\mathcal{E}_{c, \max }(\%)\end{array}$} & $\mathrm{i}=1$ & 0.44 & 0.29 & $(0.16)$ & 0.21 & 0.11 \\
\hline & $\mathrm{i}=2$ & 0.20 & 0.45 & $(0.24)$ & 0.13 & 0.13 \\
\hline
\end{tabular}

と Case2-5 については, どちらも一回加振時には最大曲げ歪位置の 曲げ歪が弾性比例限界歪を超えるものの終局状態とはならず，二回 目加振時に Case2-4 のみ終局状態となった。

\subsection{2 補強部の有無による杭最大曲げ歪位置の違い}

表 5 に, Case 2 シリーズの最大作用圧縮軸力，地盤液状化後から最 大曲げ歪時(Case2-4, Case2-5 については加振終了時)までの最大曲げ歪 $\varepsilon_{b, \max }$ と最大圧縮軸歪 $\varepsilon_{c, \max }$ を示す。杭の軸歪は, 困 1(b)の杭前後面に貼 付した歪ゲージ值の平均值 $\varepsilon_{\mathrm{ci}}=\left(\varepsilon_{\mathrm{pxi}}+\varepsilon_{\mathrm{pyi}}\right) / 2$ として求めている。 Case2-1 Case2-3 の各試験体について，最大軸力は補強部の有無によ らずほぼ等しい。最大曲げ歪は，補強無しの Case2-1 では杭頭部 i=1の 位置，補強部を有する Case2-2，Case2-3 では非補強部上端 $\mathrm{i}=2$ の位置に 生じている。杭頭補強杭の場合, 補強部と非補強部の境界における非補 強部上端の曲げ歪が $i=2$ の位置の值よりも大きくなっているものと推 測される。なお，Case2-3 は杭頭部 A1 の歪ゲージが加振中に断線し たため途中から計測できなかったが，他の杭の結果から $\mathrm{i}=1$ よりも i=2 の曲げ歪が大きくなることを確認している。そこで，杭 4 本の うちで曲げ歪が最大となった杭 $\mathrm{A}$ の非補強部上端 $\mathrm{i}=2(\mathrm{~A} 2)$ の結果を 記載するとともに，杭 $\mathrm{A}$ の奥の杭 C の結果を併せて示している。

図 16 に Case2-1 と Case2-2 の最大曲げ歪時の杭曲げ歪分布，写真 1 に最終変形状態を示す。図 16 より Case2-1 と Case2-2 では最大曲 げ歪位置における曲げ歪が降伏歪 $\varepsilon_{y}$ に達している。また，縦破線は 初期圧縮軸力を考慮した杭の降伏歪 $\varepsilon_{\mathrm{yn}}\left(=\varepsilon_{\mathrm{y}}\left[1-\mathrm{N}_{0} / \mathrm{N}_{\mathrm{y}}\right]\right)$ を示しており, 最大曲げ歪時には杭頭部及び下端部の二箇所以上で曲げ歪が $\varepsilon_{y n}$ に 達している。なお，最大曲げ歪時以降は杭頭および非補強部上端の 曲げ歪が急激に低下した。写真 1 に示すような「くの字」型の最終 変形状態は，杭頭や非補強部上端が局部変形を生じ，杭が作用曲げ モーメントを負担できなくなったために，杭中央部から下部の範囲 に損傷が集中したことによるものと考えられる。最大曲げ歪時以降 に計測できた曲げ歪分布についても，写真 1 と同様の「くの字」型 となっていることを確認している。また，試験体には最終変形時に おいて，実大スケールで $0.4 \mathrm{~m}$ 程度の地盤沈下がみられ，杭頭及び 杭頭補強部が突出していた。

図 17 に, 一回目加振時に終局状態とならなかった地盤相対密度 Dr $=60 \%$ の試験体 Case2-4 と Case2-5 について，一回目加振時の曲げ 歪 $\varepsilon_{\mathrm{b}}$ と軸歪 $\varepsilon_{\mathrm{c}}$ の履歴を示す。杭の最大曲げ歪位置は，補強無しの Case2-4 では杭 A の杭頭部 $i=1(A 1) の$ 位置, 補強部長さ 1D の Case2-5 では杭 $\mathrm{C}$ の非補強部上端 $\mathrm{i}=2(\mathrm{C} 2)$ である。地盤液状化後には両試験 体とも, 最大曲げ歪位置における曲げ歪と軸歪のベクトルが軸力を 考慮した弾性比例限界歪を超えているが，Case2-5 では最大曲げ歪 位置である C2 の曲げ歪の増加が抑制されており，最大曲げ歪值は 補強無しの Case2-4よりも小さくなっていることが分かる。

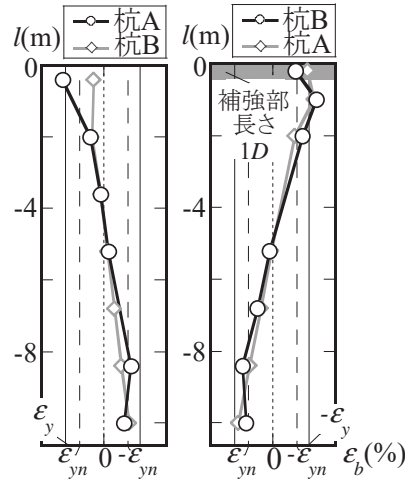

(a) Case2-1 (b) Case2-2

図 16 最大曲げ歪時曲げ歪分布

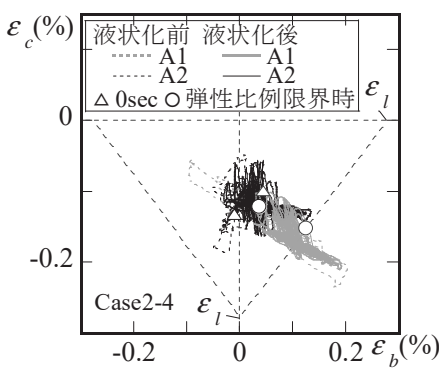

(a) Case2-4

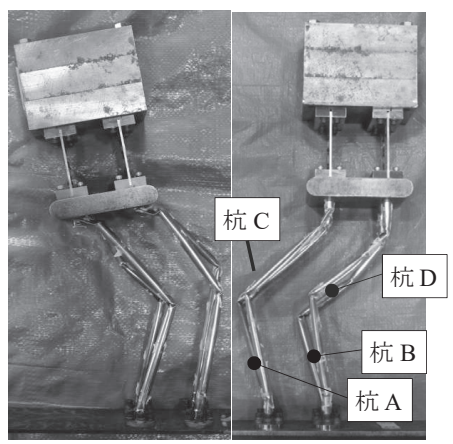

(a) Case2-1 写真 1 最終変形状態

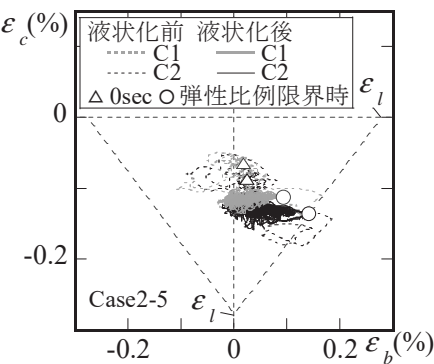

(b) Case2-5
図 17 杭の曲げ歪と軸歪の履歴（加振一回目）

\section{2 軸力と水平力を受ける杭頭補強鋼管杭の弾塑性大変形解析}

本節では，弾塑性大変形解析により液状化地盤において軸力と水 平力を受ける，杭頭補強鋼管杭の曲げ座屈性状を明らかにする。

図 18 に, 地盤相対密度 $D r=30 \%$, 液状化地盤における低減率 $\beta=0.1$ において，杭頭補強部長さと軸力比が異なる杭の作用曲げモーメン 卜分布を示す。縦軸は杭の材軸方向の位置 $\mathrm{x}$ を材長 |で除したもの である。横軸は 4.1 節の遠心載荷実験結果より, 杭頭水平変位が $0.8 \mathrm{~m}$

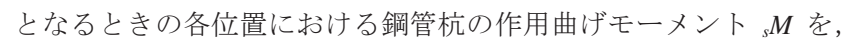
軸力を考慮した鋼管杭の全塑性モーメント ${ }_{s} M_{p c}$ で除したものである。 図中には参考として, Case2-1 Case2-3 の最大曲げ歪時の実験結果を 示している。比較のため Case2-1 と Case2-3 は曲げモーメントの符 号を反転している。なお，遠心載荷実験で得られた曲げ歪から作用 曲げモーメントを算出する際には，文献 8)の曲げモーメントー曲げ 歪関係モデルを用いることとする。また，ここでは鋼管に作用する 曲げモーメント分布を明らかにするため，補強部においても鋼管が 負担する曲げモーメントを掲載している。

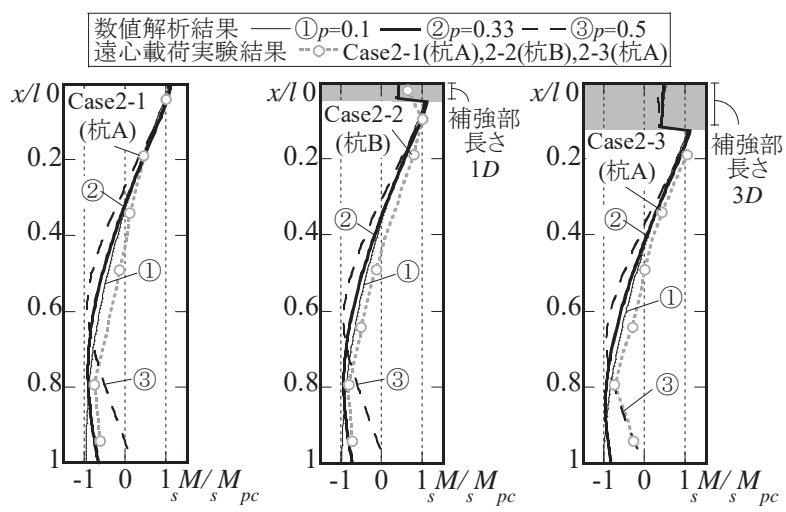

$\begin{array}{lll}\text { （a）補強無し } & \text { (b) 補強部長さ 1D } & \text { （c）補強部長さ } 3 D\end{array}$ 図 18 杭の作用曲げモーメント分布 
図 18 の無次元化曲げモーメント分布において, 数值解析結果より 杭頭及び非補強部上端の曲げモーメントが最大となり, ${ }_{\mathrm{s}} \mathrm{M} / \mathrm{s} \mathrm{M}_{\mathrm{pc}}=1$ に 達している。補強部を有する場合 (図 18(b),(c)) の杭頭曲げモーメ ントは, 軸力比 p によらず補強無しの場合（図 18(a)）よりも低減し ており, 補強部長さ $1 \mathrm{D}$ では 0.37 倍, 補強部長さ $3 \mathrm{D}$ では 0.42 倍と なっている。補強部長さ $1 \mathrm{D}$ と $3 \mathrm{D}$ で杭頭曲げモーメントの低減率が 異なる理由は以下の通りである。上述の通り，鋼管のみである非補 強部上端では曲げモーメントが全塑性モーメント $\left({ }_{s} \mathrm{M} / \mathrm{s} \mathrm{M}_{\mathrm{pc}}=1\right)$ に達 する。補強部下端では補強部（鋼管+中詰め材）と非補強部（鋼管） の断面係数の比により曲げモーメントが低減されており, この低減 率は軸力比 $p=0.33$ の場合, 補強部長さ $1 D$ で $36.5 \%, 3 D$ で $36.4 \%$ と ほぼ等しい。補強部では曲げモーメントが補強部下端から杭頭に向 かってほぼ等しい傾きで増加していることから, 補強部が長いほど 杭頭部の曲げモーメントが大きくなったといえる。

一方, 補強部長さと軸力比の異なる杭の最大水平荷重を比較する と, 補強無しの場合に対寸る杭頭補強杭の荷重上昇率は, 補強部長 さ $1 \mathrm{D}$ と $3 \mathrm{D}$ において, $\mathrm{p}=0.1$ ではそれぞれ $5.3 \%$ 及び $16.3 \%, p=0.33$ では $8.5 \%$ 及び $26.0 \%, p=0.5$ では $10.0 \%$ 及び $32.5 \%$ となっている。杭 頭補強杭は杭頭部の曲げ耐力が上昇することに加え, 座屈長さ低減 による座屈耐力上昇効果を有することから, 補強部長さまたは軸力 比が大きいものほど, 耐力向上が顕著となったものと考えられる。

\section{3 液状化地盤における杭頭補強鋼管杭の終局耐力評価}

本節では杭頭補強鋼管杭を対象に, 3.4 節で求めた杭の曲げ座屈 耐力と全塑性モーメントを適用した現行の設計指針 ${ }^{199}$ のの M-N 設計 耐力曲線, M-N 設計耐力線により, 鋼管杭の作用軸力と作用曲げモ ーメントの相関による終局耐力評価を試みる。

図 19 に, Case2-1 Case2-5 における作用軸力及び作用曲げモーメ ントと, 現行の設計指針 ${ }^{199)}$ の M-N 設計耐力曲線, M-N 設計耐力線 及び文献 11)の終局耐力曲線の比較を示寸。図中の縦軸は杭の作用 軸力 $\mathrm{N}_{\mathrm{b}}$ を(20a) (20c)式の弾塑性座屈耐力 $\mathrm{N}_{\mathrm{cr} 0}$ で除したものである。 横軸は各履歴における杭の作用曲げモーメントM を鋼管杭の全塑 性モーメント ${ }_{s} M_{p}$ で除したものであり，作用曲げモーメントには Case2 シリーズの試験体の最大曲げ歪位置（i=1 または $\mathrm{i}=2$ 位置）の 作用曲げモーメントを適用している。時刻歴中の代表的な履歴とし $て$, 地盤液状化後の最大軸力時, 曲价歪増分最大時, 最大曲げ歪時 までの軸力と曲げモーメントの履歴を細点線で結んでいる。終局状 態となった Case2-1 Case2-3 において, 灰色プロットは曲げ歪増分 最大時 (図 14(e), 図 15(e)の『もしくはム), 黒プロットは最大曲げ 歪時(図 14(e), 図 15(e)の『もしくは Case2-3 については, 非補強部上端が最大曲げ歪となる時刻の杭頭 部 $\mathrm{i}=1$ の作用曲げモーメントを, 中詰部材充填部の全塑性モーメン ト $\mathrm{M}_{\mathrm{p}}$ で除した值として黒プロットで示している。なお， $\mathrm{f} M \mathrm{p}$ は鋼管 杭と中詰部材の全塑性モーメントを累加して求めている。また Case2-3 については杭 A 杭頭部 $\mathrm{i}=1$ (A1)の歪ゲージが加振中に断線し たため, 参考として杭 C の $\mathrm{i}=1(\mathrm{C} 1)$ の結果を掲載している。×及び +は, 4.2 節の弾塑性大変形解析の最大耐力時における杭頭部及び 非補強部上端の結果である。図中の黒実線は文献 11)で提示された 終局耐力曲線, 黒破線と黒一点鎖線はそれぞれ建築基礎構造設計指 針 ${ }^{1)}$ の設計耐力曲線, 限界状態設計指針 ${ }^{9}$ の設計耐力線である。こ れらの耐力式を次式に示す。

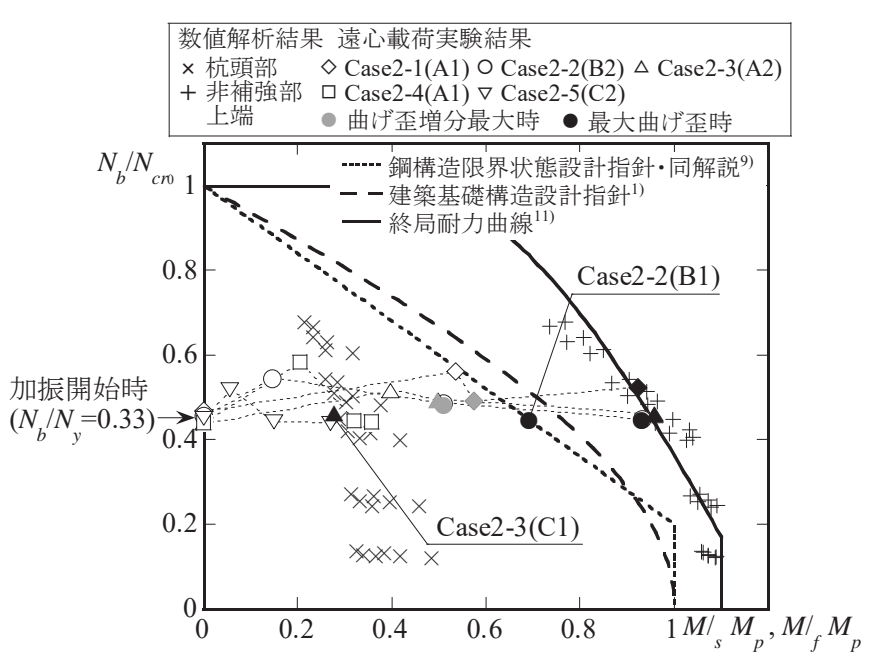

図 19 最大曲げ歪位置における杭の終局耐力評価

文献 11)の終局耐力曲線(非弾性地盤) :

$$
\begin{aligned}
& \mathrm{N} / \mathrm{N}_{\text {cr } 0}=\cos \left[2\left(\mathrm{M}_{\mathrm{N}} \mathrm{M}_{\mathrm{p}}-0.4\right)\right] \quad\left(0.4<\mathrm{M} / \mathrm{M}_{\mathrm{p}} \leq 1.1\right) \quad(21 \mathrm{a})^{\text {文献 } 11)(15) \text { 式 }} \\
& \mathrm{N} / \mathrm{N}_{\text {cr } 0}=1.0 \\
& \left(M / M_{p} \leq 0.4\right)(21 b)^{\text {文献 } 11)(15) \text { 式 }}
\end{aligned}
$$

建築基礎構造設計指針 ${ }^{1)}$ :

$$
\mathrm{M} / \mathrm{M}_{\mathrm{p}}=\cos \left[(\pi \mathrm{N}) /\left(2 \mathrm{~N}_{\mathrm{y}}\right)\right]
$$

(22) 文献 1) (6.7.5)式

鋼構造限界状態設計指針・同解説 ${ }^{9)}$ :

$$
\begin{array}{lll}
M / M_{p} \leq 1.0 & \left(N / N_{y} \leq 0.2\right) & (23 a)^{\text {文献 9) (3.24e)式 }} \\
N / N_{y}+0.80 M / M_{p} \leq 1.0 & \left(N / N_{y}>0.2\right) & (23 b)^{\text {文献 9)(3.24)式 }}
\end{array}
$$

本論文では, 曲げ座屈を考慮し, (22) (23)式の $\mathrm{N}_{\mathrm{y}}$ に(20a) (20c) 式で求めた $\mathrm{N}_{\mathrm{cr} 0}$ を適用している。

図 19 より, Case2-1 Case2-3 の試験体の最大曲げ歪位置における 曲げ歪増分最大時の耐力は, 杭頭補強部を有する場合においても (23a), (23b)式の M-N 設計耐力線に概ね対応し, 最大曲げ歪時の耐 力は(21a), (21b)式の終局耐力曲線に対応することが示された。一方, 補強部を有する試験体について, 非補強部上端の最大曲げ歪時にお ける作用曲げモーメントと全塑性モーメントの比 $M / M_{p}$ は, 非補強 部上端で概ね 0.95 程度で終局耐力曲線上に分布するのに対し, 杭頭 部は Case2-2 で 0.69, Case2-3 で 0.28 程度にとどまっており, 図中 破線の M-N 設計耐力曲線の内側に分布している。杭頭補強杭の場合 は, 補強部の杭頭作用曲げモーメントが非補強部上端よりも大きい ものの, 断面性能はさらに大きいため, 終局時においては杭頭より も先に非補強部上端が全塑性モーメントに達している。例えば Case2-2 では, 補強部の杭頭作用曲げモーメントは非補強部上端の 2.68 倍となる一方で, 全塑性モーメントは非補強部の 3.62 倍である ことから, 最大曲げ歪時においても補強部は全塑性モーメント以下 となっていることが分かる。

\section{4 液状化地盤における杭頭補強鋼管杭の終局挙動}

本節では, 杭の作用曲げモーメント反曲点位置及び杭頭部と非補 強部上端の曲げモーメント比から, 液状化地盤における杭頭補強鋼 管杭の終局挙動を考察する。

図 20 に, 杭の作用曲げモーメント反曲点位置と水平地盤ばね定数 関係を示す。縦軸は, 図 22 に示寸杭頭から曲げモーメント反曲点ま での距離 $I_{0}$ を杭径 D で除したもの, 横軸は水平地盤ば水定数 $K_{c}$ で ある。各プロットは, 軸力比 0.33 , 補強部長さが $0,1 \mathrm{D}, 3 \mathrm{D}$ の場合 
の弾性時の数值解析結果及び Case2 の遠心載荷 実験における液状化前の曲げ歪振幅の最大時, 液状化後の曲げ歪増分最大時, 最大曲げ歪時の 結果を示す。数值解析結果では, 補強部長さに よらず水平地盤ば衫定数が小さくなると, 杭頭 から反曲点までの距離は長くなっている。また 遠心載荷実験結果より, 地盤液状化後の杭頭か ら反曲点までの距離は液状化前よりも長くなっ ていることが分かる。

図 21 に, 杭頭部と非補強部上端の作用曲げモ ーメント比と反曲点位置の関係を示す。縦軸は, 杭頭補強鋼管杭の杭頭部の曲げモーメント $M_{1}$

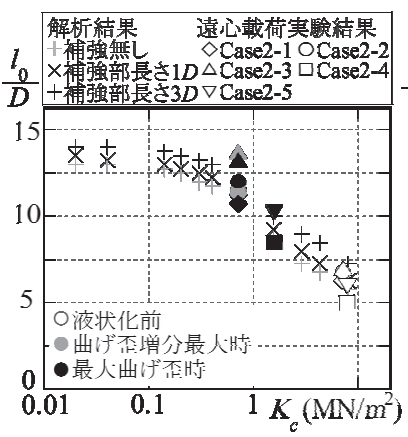

図 20 水平地盤ばね定数 曲げモーメント反曲点 位置関係

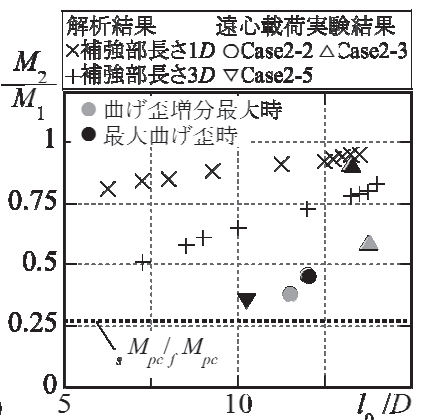

図 2

\section{曲げモーメント反曲点位置 杭頭部と非補強部上端 曲げモーメントの割合}

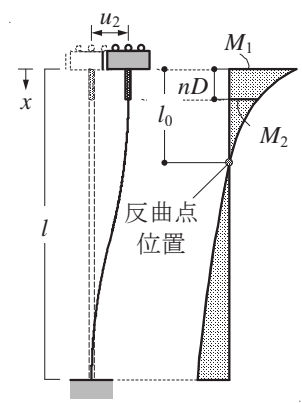

図 22 杭曲げモーメント 分布概略図
に対する非補強部上端の曲げモーメント $M_{2}$ の割合 $M_{2} / M_{1}$ であり， 図中の ${ }_{s} M_{p c} / \mathrm{M}$ pc は軸力比 0.33 時における鋼管と中詰部材充填部の全 塑性モーメントの割合を示す。なお，数值解析結果及び遠心載荷実 験結果は, 図 20 のプロットと同じものである。数值解析結果より, 杭頭から反曲点までの距離が長くなると杭頭補強部と非補強部上端 の曲げモーメントの割合 $M_{2} / M_{1}$ が大きくなっている。このため，水 平地盤ば煞定数が低下寸る場合(地盤液状化時), 図 20 上り杭頭から 反曲点までの距離が低下前よりも長くなることから， $M_{2} / M_{1}$ が 1 に 近づき，曲げ耐力の大きい杭頭補強部よりも先に非補強部上端で全 塑性モーメントに達する可能性が高くなったものと考えられる。

一方で Case2 の遠心載荷実験においては, 動的加振により杭頭部 に慣性力が集中し, 杭頭の作用曲げモーメントが大きくなったため, 補強部長さ1D の試験体 Case2-2 と Case2-5 で $M_{2} / M_{1}$ が小さくなって いる。ただし本試験体の ${ }_{\mathrm{s}} \mathrm{M}_{\mathrm{p} / \mathrm{f}} \mathrm{M} \mathrm{pc}$ は 0.28 と小さいことから, Case2-2 についても Case2-3 と同様に, 最大曲げ歪時に非補強部上端が全塑 性モーメントに達し，終局状態となったものと考えられる。

\section{5. 結}

本論文では杭頭補強鋼管杭を対象とした上屋・杭基礎一地盤系の 遠心載荷実験を行い, 液状化地盤において軸力と曲げモーメントが 作用する杭の終局耐力を明らかにした。以下に得られた結論を示す。 1）液状化地盤における杭の応答時刻歴より，基礎部の水平変形を 許容したときの杭の曲げ歪応答は, 補強無しの場合は杭頭で曲 げ歪が増大し最大となる。一方，杭頭補強を有する場合は補強 部の断面性能が高く, 杭頭曲げ歪の増加が緩やかになるため, 非補強部上端の曲げ歪が増大して最大となることを示した。

2) 軸力のみを受ける杭の弾塑性大変形解析及び遠心載荷実験によ り，杭頭補強部を有する杭の座屈耐力を明らかにした。補強部 を有する杭は補強無しよりも座屈耐力が上昇し, 耐力上昇率は 実験の場合で $4 \%$ 程度となった。弾塑性大変形解析では, $n=0 \sim 3$, $\lambda=58 \sim 179, \mathrm{~K}_{\mathrm{c}}=0.01 \sim 1.0 \mathrm{MN} / \mathrm{m}^{2}$ の解析範囲において, 最大 $12 \%$ 程 度上昇することを確認した。また，杭頭補強杭の弾塑性曲げ座 屈耐力は, 液状化地盤による杭の水平変形拘束効果を考慮して エネルギー法により誘導した弾性曲げ座屈荷重式を適用した修 正一般化細長比による座屈曲線 ${ }^{9110)}$ で評価できることを示した。 この座屈曲線は基礎部の水平変形を拘束した遠心載荷実験の動 座屈耐力とも概ね対応しており, 妥当性が検証された。

3）液状化地盤において，軸力と曲げモーメントを受ける杭頭補強
鋼管杭の耐力は，最大曲げ歪位置を対象として，曲げ歪増分最 大時では鋼構造限界状態設計指針・同解説 ${ }^{9}$ の $\mathrm{M}-\mathrm{N}$ 設計耐力線 に 2)の座屈曲線より求めた動座屈耐力と全塑性耐力を適用する ことで概ね評価でき, 最大曲げ歪時では文献 11)の終局耐力曲線 により評価できることを示した。

4) 軸力と水平力を受ける杭の数值解析結果により, 液状化地盤時 は杭の作用曲げモーメント反曲点位置が非液状化時よりも下が り, 杭頭部に対する非補強部上端の曲げモーメントの割合が大 きくなることを示した。

\section{謝辞}

本論文は,「日本鉄鋼連盟 研究分野指定助成」による成果である。 ここに深く感謝の意を表す。

\section{参考文献}

1) 日本建築学会：建築基礎構造設計指針, 2001

2) 建設省建築研究所編： 建設省総合技術開発プロジェクト「新建築構造体 系の開発」性能評価分科会 基礎 WG 最終報告書

3) 日本建築学会災害委員会：2011 年東北地方太平洋沖地震災害調査, 2011.9 4) 木村祥裕, 時松孝次：液状化地盤において鉛直荷重を受ける鋼管単杭の 曲げ座屈応力度, 日本建築学会構造系論文集, 第 595 号, pp. 77-78, 2005.9

5) 木村祥裕, 時松孝次：液状化地盤において杭頭水平変位を伴う鋼管単杭 の曲げ座屈応力度, 日本建築学会構造系論文集, 第 617 号, pp. 169-175, 2007. 11

6) 木村祥裕, 時松孝次：液状化地盤において杭頭回転拘束を受ける鋼管単杭 の曲げ座屈応力度, 日本建築学会構造系論文集, 第 74 巻, 第 638 号, pp. 721-730, 2009. 4

7) 木村祥裕, 岸野泰典, 田村修次：遠心載荷装置を用いた上屋・杭基礎一液 状化地盤系における中空円形断面杭の動座屈実験, 日本建築学会構造系論 文集, 第 80 巻, 717 号, pp. 1707-1716, 2015. 11

8) 木村祥裕, 後藤天志郎, 的場萌子, 田村修次：遠心載荷実験装置を用いた 上屋・杭基礎-地盤系における液状化地盤の鋼管杭の動的メカニズムと終 局耐力, 日本建築学会構造系論文集, 第 81 巻, 第 730 号, pp. 2079-2089, 2016. 12

9) 日本建築学会： 鋼構造限界状態設計指針・同解説, 2010

10) 日本建築学会：鋼構造設計規準・同解説, 2005

11) 木村祥裕, 時松孝次：液状化地盤において一定軸力及び水平力を受ける鋼 管杭の最大耐力と終局曲げモーメント, 日本建築学会構造系論文集, 第 77 巻, 第 675 号, pp. 775-781, 2012. 5

12)木村祥裕, 小河利行, 佐伯英一郎：製造方法の異なる冷間成形鋼管の局部 座屈挙動, 鋼構造論文集, 第 8 巻, 第 29 号, pp. 27-34, 2001.3

13) 田村修次, 肥田剛典：地震時土圧と側面摩擦力を考慮した応答変位法によ る杭応力評価, 日本建築学会構造系論文集, 第76巻, 第 670 号, pp.2115-2121, 2011. 12 


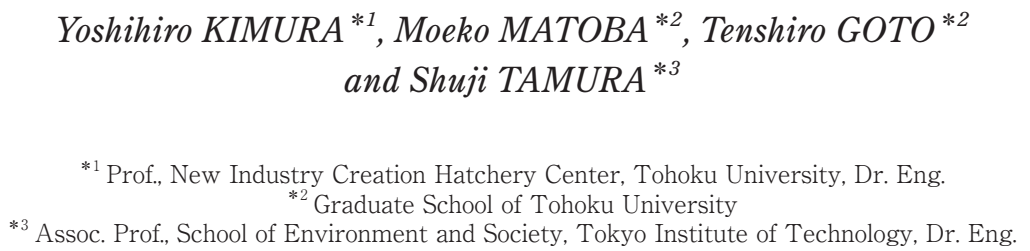

In our previous paper, centrifuge tests of superstructure-pile-liquefied soil systems have been conducted, and dynamic ultimate mechanism of steel piles subjected to the vertical force and horizontal force in the liquefied soil was clarified. It is shown that piles' ultimate strength was estimated using the M-N interaction curves. In the other hand, for real structures, reinforced concrete is filled at a pile head to fix a connection between steel piles and a reinforced concrete footing beam. It is considered that the flexural buckling length of steel piles becomes shortened because pile head filled with concrete acts as the rigid body. In this paper, centrifuge tests of superstructure-pile-liquefied soil systems are conducted to compare the dynamic ultimate mechanism of steel piles reinforced at pile heads with that of non-stiffened ones. Subsequently, piles' ultimate strength is estimated using M-N interaction curves with pile's equivalent buckling slenderness ratio.

Figure 1 shows a specimen of centrifuge tests. The specimen is configured by a superstructure represented consisting of a mass and a pair of spring elements, four piles and a saturated sand layer. In this paper, an aluminum cross section member is inserted into the pile head of a specimen to reproduce a real pile reinforced filled with concrete at the pile head. In Case 1, the pile cap is laterally fixed, and then only varying axial force acts on the piles. In Case 2, the pile cap can laterally move, and the vertical and horizontal forces act on the piles. The centrifuge tests were performed under centrifugal acceleration $40 \mathrm{~g}$.

Figures 7 and 8 show the response time histories of Case 1 specimens and table 5 shows the pile' $\mathrm{s}$ maximum axial force. It is shown that the bucking strength becomes larger as reinforcement length at the pile head is longer

Figures 14 and 15 show the response time histories of Case 2 specimens. For all Case 2 specimens, the bending strain increased immediately after soil liquefied.

For specimens of Case 1, the dynamic buckling strength of piles is evaluated. Figure 13 shows the relationship between observed pile' s dynamic buckling strength subjected to only vertical load and buckling curves for Japanese limit state design of steel structures and Japanese design standard for steel structures. Here, the equivalent slenderness ratio is calculated by the ratio of pile's elastic flexural buckling load to the yield load. For a pile reinforced at the pile head, elastic flexural buckling load developed by the energy method in Section 3.3 is applied. The buckling curve of Japanese recommendations for limit state design of steel structures is lower bound of flexural buckling strength of piles in the liquefied soil. As the results, it is shown that the buckling stress curve with the equivalent slenderness ratio can be applied to estimate flexural buckling stress of pile reinforced at the pile head.

Next, for piles subjected to lateral and vertical forces, ultimate strength is evaluated using Japanese current design criteria. Figure 19 shows the relationship between ultimate strength of piles on centrifuge tests and the M-N interaction curves for the design criteria. The axial force of piles is divided by elastic-plastic buckling stress of piles obtained from buckling curve of Japanese recommendations for limit state design of steel structures as shown in Fig. 13, and the bending moment at the maximum bending strain position is divided by the full plastic moment of piles. It is shown that the M-N interaction curves of Japanese recommendations for design of building foundation is lower bound of pile's ultimate strength in the liquefied soil at the maximum bending strain 